Florida International University FIU Digital Commons

\title{
Trees in the Agricultural Matrix: Reforestation Processes in a Tropical Dry Landscape in Chinandega, Nicaragua
}

Brittany A. Duffy

bduff002@fiu.edu

DOI: $10.25148 /$ etd.FIDC000716

Follow this and additional works at: https:// digitalcommons.fiu.edu/etd

Part of the Environmental Studies Commons, Natural Resources and Conservation Commons, and the Natural Resources Management and Policy Commons

\section{Recommended Citation}

Duffy, Brittany A., "Trees in the Agricultural Matrix: Reforestation Processes in a Tropical Dry Landscape in Chinandega, Nicaragua" (2016). FIU Electronic Theses and Dissertations. 2608.

https://digitalcommons.fiu.edu/etd/2608 
FLORIDA INTERNATIONAL UNIVERSIY

Miami, Florida

TREES IN AN AGRICULTURAL MATRIX:

REFORESTATION PROCESSES IN A

TROPICAL DRY FOREST LANDSCAPE IN CHINANDEGA, NICARAGUA

A thesis submitted in partial fulfillment of the

requirements for the degree of

MASTER OF SCIENCE

in

ENVIRONMENTAL STUDIES

by

Brittany Duffy

2016 
To: Dean Michael R. Heithaus

College of Arts, Sciences and Education

This thesis, written by Brittany Duffy, and entitled Trees in an Agricultural Matrix:

Reforestation Processes in a Tropical Dry Forest Landscape in Chinandega, Nicaragua, having been approved in respect to style and intellectual content, is referred to you for judgment.

We have read this thesis and recommend that it be approved.

Mahadev Bhat

Joel Heinen

David B. Bray Major Professor

Date of Defense: July 6, 2016

The thesis of Brittany Duffy is approved.

Dean Michael R. Heithaus

College of Arts, Sciences and Education

Andrés G. Gil

Vice President for Research and Economic Development

and Dean of the University Graduate School

Florida International University, 2016 


\section{DEDICATION}

I dedicate this thesis to my family: Mom, Dad, Ian, Evan, Owen, Grandma, Gigi, Alyssa, and my loving husband Kevin: thank you for the wisdom, patience, humor and kindness that have kept me going. I'll try to pay it forward. 


\section{ACKNOWLEDGMENT}

I would like to thank the members of my committee for their support, patience and dedication to the education of their students. I would like to thank Dr. Bhat and the USDA, who helped fund this research with a National Hispanic-serving Institutions grant, and Dr. Heinen, whose dedication to conservation is inspirational. I owe a debt of gratitude to the Peace Corps, especially Peter, Miguel, Patrick and Felix, who gave me the opportunity, tools, training and pep talks I needed to conduct this research while having the adventure of a lifetime. I am also thankful to Jennifer Tisthammer and the Deering Estate, whose funding helped finalize this project and helped me define my purpose. Finally, I would like to thank my advisor, Dr. David Bray, whose guidance, expertise, and much needed prodding helped me when I was flailing, and without whom I would not have achieved this accomplishment.

I have found my coursework throughout the Natural Resource Management program to be stimulating and thoughtful, providing me with the tools with which to explore, understand and protect the natural resources that sustain our world. 


\begin{abstract}
OF THE THESIS
TREES IN AN AGRICULTURAL MATRIX:

REFORESTATION PROCESSES IN A

TROPICAL DRY FOREST LANDSCAPE IN CHINANDEGA, NICARAGUA. by

Brittany Duffy
\end{abstract}

Florida International University, 2016

Miami, Florida

Professor David B. Bray, Major Professor

Tree management practices in the tropical dry forest region of Nicaragua were examined to determine opportunities and factors influencing tree-planting initiatives and forest recovery within the agricultural matrix. A 217.11 ha tree inventory and 44 social surveys were conducted in three rural communities. The inventory found 88 species, $66.68 \%$ were native, and 70 valued for multiple uses. Farmers' reasons for maintaining trees varied, emphasizing live fencing, wood, and fruit. The landscape also contains a tree plantation and a riparian forest, and the origins and management of these tree cover components of the landscape are also considered. Tree planting interventions should supplement extant stakeholder motivation with technical training and basic materials only as explicitly requested by participants, rather than imposing costly or inappropriate project preferences. Initiatives should also focus on smallholders and on multi-use native species suggested by stakeholders in order to maximize the economic, social and environmental benefits provided. 


\section{TABLE OF CONTENTS}

CHAPTER

PAGE

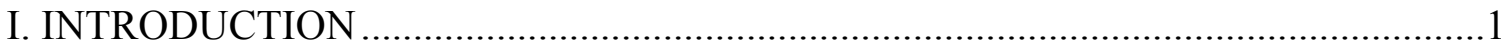

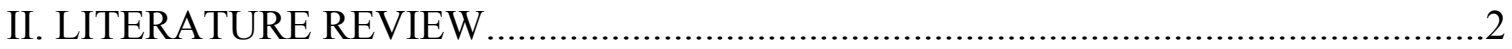

On-Farm Tree Cover and Services Provided ....................................................... 2

Factors Influencing Farmers in Tree Adoption and Management .........................9

Projects that Attempt to Promote Trees in Landscapes .......................................11

The Central American Tropical Dry Forest and Tree Planting Initiatives..............14

Study Site and Methods ...........................................................................2

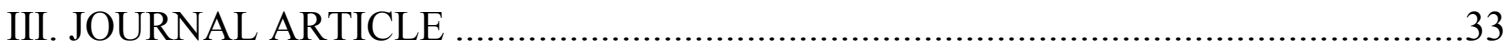

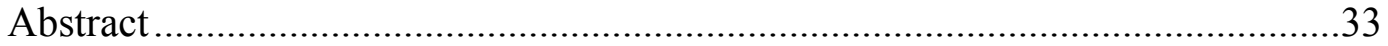

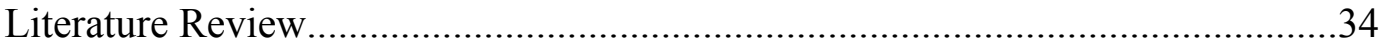

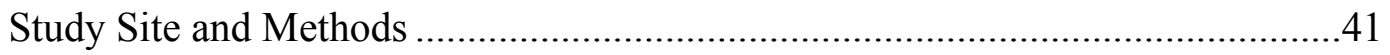

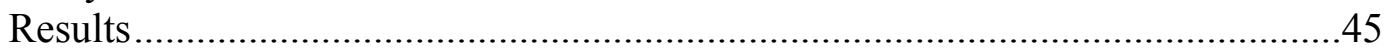

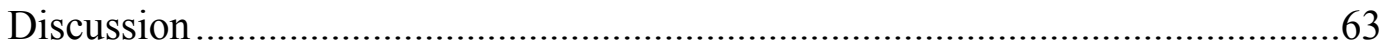

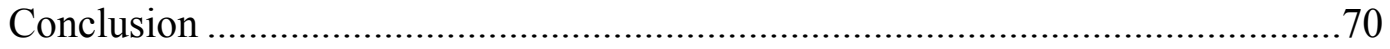

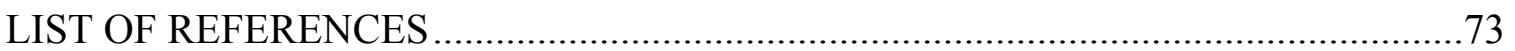

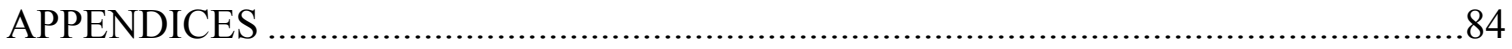


1. Reasons Cited for Maintaining Individual Trees by Number of Species and Origin of Trees

2. Species with Over 100 Individuals Inventoried................................51

3. Tree Planting Projects in the Three Communities Since $1990 \ldots \ldots \ldots \ldots \ldots \ldots \ldots \ldots \ldots . . .53$

4. Peace Corps Tree Planting Project 2013-2015 ..................................55

5. Factors Influencing Participation in the Tree Planting Projects....................57

6. Number of Trees Reported Cut by Loggers within the 3 Communities, May to

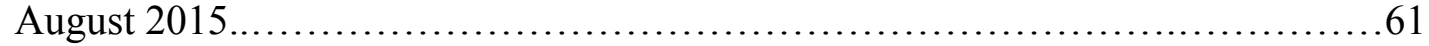

7. Species Inventoried and Their Uses.......................................... 84 


\section{ABBREVATIONS AND ACRONYMS}

$\begin{array}{ll}\text { INTA } & \text { Nicaraguan Institute of Agricultural Technology } \\ \text { LP } & \text { La Pinta } \\ \text { MCC } & \text { Millennium Challenge Corporation } \\ \text { P } & \text { Pinolillo } \\ \text { T } & \text { Trinitaria } \\ \text { TPH } & \text { Trees per hectare } \\ \text { TDF } & \text { Tropical dry forest }\end{array}$




\section{CHAPTER I}

\section{INTRODUCTION}

The following chapter is a broad literature review providing material pertinent to the understanding of trees in an agricultural matrix in a tropical dry forest landscape in Chinandega, Nicaragua. The review analyzes published data about current agricultural conversion of forests, trees that remain within the agricultural matrix, farmers' perceptions of these trees, agroforestry possibilities within the tropical dry forest of Nicaragua, past and current reforestation efforts in this region, and a synopsis of the study site and methods that were conducted for this thesis. Chapter 3 is designed as a journal article for submission to Agroforestry Systems, in which a synthesized version of Chapter 2 is followed by the results and analysis of this investigation, focusing on current quantity and diversity of tree cover within the agricultural matrix, farmers' values thereof, interactions between landscape elements, and suggestions for future tree-planting projects. 


\section{CHAPTER II}

\section{LITERATURE REVIEW}

\section{On-Farm Tree Cover and Services Provided}

Throughout the world, many forests have been replaced by cropland and pasture. This has been important in increasing local food security and enhancing global food production, but there have also been costs associated with these developments, as it is the leading cause of faunal decline around the globe. The process has supplanted rich diversity with monocultures and sharply reduced ecosystem services and biodiversity conservation formerly provided by intact forests (Robinson and Sutherland 2002, Diaz et al. 2005, Fischer et al. 2010). The ecological damage and reduction of diversity of the ongoing forest conversion is well noted, but continues despite increasing recognition of the importance of forest conservation and restoration. However, a solution is far more complicated than simply reducing agricultural land or increasing protection of forests (Pfund et al. 2011).

While conservation of forests should be encouraged, efforts must recognize the growth of human-dominated lands and look to work within these areas to promote forest restoration, providing habitat for at least some forest species, and enrichment of agricultural landscapes with trees (Daily et al. 2003). Current reserves are being encroached upon by the rapidly expanding agricultural frontier, a trend that will continue to intensify as food demand increases (Godfray et al. 2010). As a result, biodiversity conservation efforts are increasingly looking towards at least partial restoration of these human-modified landscapes to provide ecosystem services and tree cover and habitat (Mendoza et al. 2014). 
The understanding of how to recreate habitat for biodiversity within anthropogenically-modified landscapes is aided by concepts from landscape ecology. When viewed from above, landscapes commonly form a mosaic of several landscape elements, which can vary from residential neighborhoods to fields to forests, and are separated by distinct boundaries like roads. or connected by corridors such as riparian forests. The basic spatial framework for landscape analysis is contained in the concept of the patch-corridor matrix (Forman 1995). The spatial language developed by landscape studies can be applied to any land mosaic, providing an analysis and comparison tool, acknowledging boundaries and attempting to understand the networks and patterns. Patch size, connectivity, and isolation of habitats, directly affect species abundance, persistence, and dispersal success (Eriksson and Ehrlén 2001). While isolated fragments limit gene flow, dispersal success should increase as patch size and connectivity increase, allowing greater movement, flow and interaction (Forman 1995, Lawton 2010). The landscape framework, for example, can explain the recolonization rate of a locally extinct species. Boundaries between landscapes will be determined by a change in the sequence and type of plots, such as when a suburban landscape may include neighborhoods, parks, and shopping areas. A tarmac road may ring these areas before encountering an agricultural matrix, forming a mosaic comprised of at least $50 \%$ fields, hedgerows, woodlots, stream corridors and farm roads. Where an agricultural matrix dominates an area and has significantly displaced earlier ecological processes, scattered heterogeneous forest patches connected by corridors, such as live fences, and vegetation-protected water courses in riparian forests can create habitat and facilitate movement of species, forming patterns that enable both a degree of conservation and human land-use (Forman 1995, 
McGarigal and Kushman 2002, Townsend and Levey 2005). Global land use policies and proposals have in recent years undergone significant shifts to encourage connectivity in landscapes, such as hedgerows, woodlands, reserves and other landscape components within the agricultural zone (Humphrey et al. 2015). Rather than the false dichotomy of human-exclusion reserves versus agricultural biodiversity wastelands, increasing biodiversity on farms and in agricultural landscapes by implementing wildlife friendly farming methods can ensure habitat resources and connectivity while taking advantage of ecosystem services and improving food production (Tschamtke et al. 2012).

Small, diversified farms have demonstrably proven more productive per area than high-input monocultures (Keating et al 2010). Because smallholder systems form the foundation of global food security, both food security and environmental policies should require eco-efficient, environmentally friendly methods and highly diversified cropping (Horlings and Marsden 2011, Tschamtke et al. 2012). As 90\% of global farmers work $<2$ ha of land, smallholders are particularly crucial, accounting for 50\% of the malnourished in the developing world and producing food in rural areas where a majority of poor people live (World Bank 2007). In order to ensure resilient smallholder systems capable of meeting the $70-100 \%$ food demand increases over the next few decades, policies should encourage sustainable techniques including reducing pesticide use, integrating soil fertility strategies, and increasing functional biodiversity to reduce environmental risks (Godfray et al. 2010, Tschamtke et al. 2012). Farming methods that incorporate these ideas include agroforestry crops like coffee and cacao, sustainable timber extraction, collection of non-timber forestry products, and the focus of this thesis, on-farm tree cover in a mosaic landscape that includes a riparian forest and a eucalyptus plantation in what 
was historically a dry tropical forest. Because crops destined for export dominate the northwest of Nicaragua, the promotion of more sustainable agriculture in this region has been limited. The most important landscape components in the agricultural matrix that constitutes the study area are trees on farms, particularly evident as live fences, a riparian forest, and a eucalyptus plantation, so I will now particularly focus on the role of these factors in reforestation and forest recovery of degraded areas.

On-farm tree cover may be categorized as secondary forest patches, woodlots, isolated trees in pasture, linear arrangements of trees found in live fences, and windbreaks. However they are classified, they are fundamentally trees on farms, where the primary productive focus of the landscape is on food production, but where trees provide some additional sources of food, materials, and ecosystem services and can increase the heterogeneity and connectivity within the agricultural matrix (Manning et al 2006, Galvez et al. 2013).

Of particular interest to this study, live fences are often established by planting large stakes of a few species that rapidly produce roots, which are then strung with several strands of barbed wire to manage livestock. Although live fences are meant to delineate fields and pasture land, they can also provide firewood, timber, fodder, and fruit, while decreasing labor and other maintenance costs. In addition to these social and economic benefits, live fences deliver important ecological services, forming linear woody features that increase connectivity and form a network within the agricultural matrix, providing habitat and resources. Of the varying types of agroforestry practices found in Central America, live fences are particularly prevalent. A study of live fences in Costa Rica and Nicaragua found that an overall high species richness of 161 different 
plant species $\mathrm{DBH}>10 \mathrm{~cm}$ were used across the sites with the main purpose of restricting animal movements (Harvey et al. 2005). Although farmers were aware of the high potential value of live fences as fodder, less than $10 \%$ deliberately made forage available because of the labor required, and few harvested the other potential products from live fences. Despite their underuse for human-production purposes, 97 migratory and even forest-dependent faunal species used the fences for a variety of purposes, including feeding, shelter, and movement corridors (Harvey et al. 2005). The prevalence of live fences, their production benefits and important ecological roles, suggest their great potential in sustainable land management, as well as their low-cost potential for establishing more trees within the agricultural mosaic (Love et al. 2009).

Also of interest to the present study, riparian forests are forested corridors that follow perennial streams or rivers, typically marked by closed canopies and limited understories. These areas have been alternately named riparian buffers, vegetated wetlands, vegetated filter strip, and other terms, and they are important as they mark the direct, dynamic interactions between terrestrial and aquatic ecosystems, affecting flood control, stream quality and nutrient uptake, trapping sediment, and providing crucial habitat (Song et al 2010). Particularly in fragmented tropical dry forest landscapes, riparian forests enhance the connectivity and movement of many bird and mammal species (Gillies and St. Clair 2008, Lees and Peres 2008). In both agricultural matrices and urban landscapes with high use of chemical inputs and nonpoint source pollution, riparian corridors act as crucial buffers, as roots absorb runoff and thereby reduce nitrate concentrations in groundwater (Speiran 2010, Newham et al. 2010). 
Tree plantations, another landscape element found in this study, are usually largescale monocultures of tree crops, with the most common being fast-wood plantations, planted to supply external markets with timber, pulp, or other products. In 2000, these plantations, mostly comprised of eucalyptus, pine, acacia and gmelina, covered 90 million hectares, growing at a rate of one million hectares per year throughout the tropics and subtropics (FAO 2001). While these plantations can provide some ecosystem services like carbon sequestration, their impacts vary depending on what ecosystem they replace (Evans and Turnbull 2004). If a plantation is placed on degraded agricultural lands that may have never been forest, this could be an optimal place for them. On the other hand, when a native forest is converted to a plantation monoculture, biodiversity is often negatively affected, and tree plantations currently account for $7 \%$ of the global tropical forest loss (FAO 2001, Hartley 2002). By removing other ecological goods and services provided by forests, such as firewood, grazing land, medicinal plants, and food, monoculture tree plantations can also have negative social and economic impacts on peasant or indigenous populations. While the carbon sequestration market has incentivized plantation expansion, their supposed benefits on hydrological and soil conditions have become a controversial issue, with provision varying widely depending on species, management practices, and environmental conditions (Gerber 2010). Eucalyptus plantations are particularly infamous for destabilizing water cycles, and their reliance on pesticides and fertilizers can cause chemical accumulation in the water supply and reduce biodiversity by negatively impacting non-target species (Hartley 2002, FSC 2004, Patzek and Pimentel 2005). Conversely, tree plantations of native species can provide a range of additional benefits, including soil stabilization, reduced erosion, 
habitat provision, seed dispersal and increased natural regeneration, and increased biodiversity (Wishnie 2007).

Though they do not host the diversity of a forest habitat, trees on farms have a positive effect on bird and insect assemblages, and are consistently used by a variety of species, including bats, rodents, and other small mammals, serving as foraging sites, additional habitat, and resting perches between fragmented ecosystems (Mendoza et al. 2014). Additionally, trees increase hydrologic services in pastures, improving soil permeation and infiltrability and reducing surface runoff, services essential to the recharge and maintenance of ground-water systems (Grinevski and Novoselova 2011, Benegas et al. 2014). Trees also mitigate flooding, increase evapotranspiration and, as being intricately connected to precipitation, may even influence rainfall patterns and increase water availability across regions, even extending wet season storage and flow into the dry season (Malmer et al. 2010, Ellison et al. 2012).

Woody vegetation increases carbon sequestration when integrated into pastures (Haile et al. 2010, Andrade et al. 2008), and certain species may be used to boost soil fertility through organic matter and nitrogen fixation, mitigating the adverse results of land degeneration (Wishnie 2007). Many landholder needs, including fuel wood, timber, shade, fodder, fruit, and natural medicines may also be addressed by increasing tree cover on their property, improving rural livelihoods and well-being while providing many of the aforementioned ecological services (Barrance 2003, Hall 2010, Place et al. 2011). Tree adoption has been positively linked to income gains as well as greater species diversity on farms, providing both social and environmental benefits (Haglund et al. 2011). 
Studies are reluctant to define appropriate or inappropriate levels of tree cover, as environmental, social and economic necessities vary across regions, but the very existence of agroforestry systems, found in a wide variety of ecological conditions throughout the globe, demonstrate their advantageous and adaptable viability (Zomer et al. 2014).

\section{Factors Influencing Farmers in Tree Adoption and Management}

Though studies agree that trees provide essential services, these functions may be perceived differently among landholders, and the differing priorities of landowners on acceptable types and quantities of trees must be considered in ensuring integration and sustainability of landscape management (Meijaard 2013, Welsch et al. 2014). Landholders may value trees for food, medicine, fuel wood, non-timber forest products, water services, conservation of biodiversity, timber, climate moderation, even religious reasons, with priorities varying over regions and affected by water availability, livestock and crop cultivation (Pfund 2011). Farmers engaged in agroforestry practices are sometimes even willing to accept some crop production loss in return for valuable tree products, including fruit and fodder (Hocking et al. 1997). In contrast, trees may sometimes be considered incompatible with agriculture, as competition for sunlight, and deforestation sometimes acceptable on the small-scale as improving local welfare (Benjamin et al. 2008, Meijaard et al. 2013).

Studies assessing farmer participation in tree adoption have highlighted several factors as influential, including gender of head of household, landholding size, soil type, market distance, family size and age distribution, (related to labor availability), annual income, irrigation availability, education level, possibly even religion (Haglund et al. 
2011, Foudnjem-Tita et al. 2013, Ashraf et al. 2015). Accessibility and tenure of land may also influence management decisions, as well as benefits (both perceived and real), and types and availability of trees (Malla 2012). These factors are underlying variables, often outside the consciousness of farmers, which condition a farmer's decision to participate and influence their preferences. In Chapter 3, several variables will be considered in assessing factors influencing farmer participation in tree planting projects, including: family size, age of head of household, gender, income source, plot size, social capital, water availability, education, and tenancy.

In addition to these underlying variables that may condition tree planting, farmer decisions about tree species and management practices can be divided into stated and revealed preferences. While both of these methods are used to analyze and forecast preference, stated preference (SP) refers to individual respondents' statements about their preferences, while the more conventional revealed preference $(\mathrm{RP})$ valuation relies on the use of some resource in the past and/or current conditions (Whitehead et al. 2008). Although these terms are usually reserved for economic evaluation of willingness to pay, they are applied to the preferences in tree cover in this study. Stated preference is demonstrated by farmers declared reason they planted their trees, while revealed preference is noted in the inventory of what trees they actually planted, deducing their preferences from their actual behavior. Trees planted by the farmers at their own expense highlight revealed preference, while tree planting projects that do not investigate or collaborate with these preferences impose inappropriate "project preferences" that fail to capitalize and connect with local circumstances. 


\section{Projects that Attempt to Promote Trees in Landscapes}

Projects with varying designs and incentives have attempted to convince farmers to plant more trees on farms. For example, landholders' decisions may be influenced by incentives from conservation policies such as Payments for Ecosystems Services (PES), high yielding, rapid-growth or varied seedlings freely given or affordably-priced, or an increase in these species market competitiveness to ensure the marginal benefits of planting trees outweigh alternative benefits (Foundjem-Tita et al. 2013). These policies are only efficacious when they interact with shifts in labor, industrial and government policy in such a way that provides incentives for forest conservation instead of deforestation (Calvo-Alvarado 2009). While some farmers regret forest and biodiversity loss, they are often driven by the simple desire to improve individual well-being, turning to agricultural practices, which are often perceived as providing faster and more secure returns (Meijaard et al. 2013). When agriculture is the only option to alleviate financial pressures, policies must consider macroeconomic factors to optimize land-use planning (Pfund 2011). A study in Costa Rica found that rather than the funding from Payments for Ecosystem Services (PSA), forest recovery in agricultural land was influenced more by the simultaneous decrease in cattle profits and increase in tourism industry, a tenuous recovery that may be negatively impacted by shifts in markets for cattle and tourism Calvo-Alvarado 2009). Rather than dangling the carrot through payments and other incentives, some governments prefer the stick, limiting timber extraction with harsh restrictions. However, forest regulations that prohibit or restrict harvesting and transporting of timber with complex, tedious, or demanding bureaucratic hurdles and permitting procedures can actually constrain or inhibit the development of agroforestry 
systems, as farmers may shy away from planting trees in fields that they will not be free to manage themselves (Detlefsen and Scheelje 2012, FAO 2013). This, as we shall see, is the case in Nicaragua.

A recent study of Panamanian cattle ranchers and small-scale agriculturalists highlights the many diverse reasons farmers may have for maintaining trees, and presents encouraging evidence in their willingness, even eagerness, to increase tree cover, specifically with native species (Garen et al. 2011), which is also reflected in this study in Nicaragua. The study analyzes the results of the Native Species Restoration Project (PRORENA), in which farmers chose the types and quantity of trees they wanted to plant from a list of available species. The project identified ninety-nine tree species that were utilized and protected by the participants, $72 \%$ of which were native. The reasons most cited for planting and maintaining trees were fruit, timber, and living fence, in that order, but $61 \%$ of the trees were valued for multiple uses, including improving the environment, providing food and shade for cattle, and supplying wood for construction, furniture and firewood (Garen et al. 2011).

Because ranching-induced deforestation was one of the main causes of unique species loss in Central and South America, the World Bank implemented an Integrated Silvopastoral project in Colombia, Costa Rica and Nicaragua to improve carbon sequestration and habitat restoration on degraded pasture with a US\$4.5 million donation. From 2002-2008, 265 small and medium-sized farms in the three countries received payments for ecosystem services by increasing live fences, windbreaks, and high-density forest plantations (World Bank 2008). While the initial payments of US\$50/ per point earned was deemed insufficient by stakeholders, an increase to US\$75 and US $\$ 110$ 
stimulated some adoption of silvopastoral practices, though PES was overestimated and the extra funds were used to monitor certain species. The project experienced some delays in the first year as funds were not available to conform to the agricultural cycle, but subsequent years were more effective than early years. The project reduced soil erosion by half, improved water quality, and the adoption of integrated silvopastoral farming systems resulted in 12,262 ha of improved biodiversity and carbon sequestration indices. Farmers also benefitted economically, demonstrating augmented milk production and stocking rates, and a dollars per hectare revenue increase of at least $60 \%$ in each country. Lessons learned from this project are being applied in the same three countries and also around the world, promoting sustainable land management in Central America, Ecuador, Brazil, and India.

Other projects, mostly underfunded, also promote the importance of on-farm tree cover. However, the lack of appropriate incentives and extension, very common in underfunded and overworked forestry ministries, may impede reforestation efforts, as farmers may have little incentive to grow trees on their own property in situations where they can still access forests, such as the riparian forest area in the study landscape (Harvey et al. 2008, Pagiola 2008, Santos-Martin 2011).

These cases demonstrate some of the variety in tree restoration policy, but there are many more alternatives currently enacted, and probably equally as many proposed solutions. The difficulty lies in applying findings to particular local or regional geopolitical, social and ecological conditions. The common time lag between academic studies, bureaucratic changes and actual policy implementation, which almost guarantees obsolescence by the time of execution, is an obstacle that must be considered in policy 
planning. Regional studies demonstrate that forest restoration strategies must be dynamic, living adaptations, involving stakeholders, integrated landscape planning and both sustainable agriculture and forest use, avoiding relying solely on restrictions or incentives that will be too dependent on constantly-shifting industry conditions (Pares-Ramos et al. 2008, Calvo-Alvarado et al. 2009).

While landowners may commonly be driven by economic factors, they face ecological constraints in their implementation and tree management techniques. These environmental requirements must be considered in restoring and maximizing ecological functions of trees on farms, particularly the promotion of native species in threatened and endangered ecosystems. Thus far, general issues in agroforestry and trees on farms have been considered through a wide lens. Now, these issues will be considered more specifically in regards to the endangered tropical dry forest of Central America, and the field site of this study in Northwest Nicaragua.

\section{The Central American Tropical Dry Forest and Tree Planting Initiatives}

The expansion of the agricultural frontier is particularly noticeable in Central America, where as much as $80 \%$ of the vegetation has been altered, including the severely threatened tropical dry forest, replacing many forest ecosystems with cropland and pasture (Harvey et al. 2008, Janzen 1988). The trend of land conversion is expected to continue, with agricultural conversion driving $69 \%$ of deforestation in the region from 2010 and beyond (Wassenaar 2007). Although perhaps not as renowned as the tropical rainforests, the Central American tropical dry forest (TDF) hosts similarly high endemic species richness and biological diversity, and is considered the most threatened of all tropical forests, covering only $1.7 \%$ of its original range and quickly losing ground as a 
result of agricultural conversion (Vieira and Scariot 2006, Calvo-Alvarado 2008, Galicia et al. 2008, Griscom and Ashton 2011).

The TDF in Central America is marked by distinct wet and dry seasons, with little to no precipitation falling from November to May. A 0.01 ha of intact TDF hosts from 7.1-12 different species of trees and shrubs, with particular representation of species form the Fabaceae, Bignoniaceae, Sapindaceae, Rubiaceae, and Euphorbiaceae, families (Gillespie et al. 2000). Some of the most abundant species include Heliathinae spp., Cordia alliodora, Guazuma ulmifolia, Tabebuia spp., Enterolobium cyclocarpum, Pachira quinata, Bursera simaruba, Gliricidia sepium, Diospyros nicaraguensis, E. salamensis, Brosimum alicastrum, Casearia corymbosa, Eugenia guatemalensis, Calcophyllum candidissimum, and Bombascopsis quinata, among others (Gillespie et al. 2000, Tarrasón et al. 2010, Griscom and Ashton 2011). While diversity is relatively high, average tree density in Central American TDF is much lower than other neotropical forests, ranging from $42-62$ trees $\mathrm{DBH} \geq 10 \mathrm{~cm}$ per $1000 \mathrm{~m}^{2}$ (Gillespie et al. 2000).

These remaining fragments demonstrate such detrimental edge effects as increase in exotic species, decreasing plant recruitment and increase in tree mortality rate, especially due to changes in the microclimate. However, perhaps as a function of its adaptability to frequent and seasonal natural disturbances, the TDF demonstrates a resilience that may allow it to recover slowly, depending on species reproduction, seasonality, and plant growth rate (Portillo-Quintero et al. 2013). The high regeneration potential of the TDF is demonstrated in areas of agricultural abandonment or forest plantations in Mexico, where secondary TDF in the state of Guerrero is recovering and is 
characterized not by fragments, but by increasing continuity and high connectivity (Galicia et al. 2008).

There are other signs that agricultural conversion is now being reversed and that tree cover is expanding modestly. Ninety-six percent of the agricultural land in Central America has retained tree cover of $>10 \%$, representing an increase of $1.6 \%$ from 2000 , with $47 \%$ showing substantial tree cover of $>30 \%$ perhaps attributed more to increased canopy cover of maturing trees rather than new trees (Zomer et al. 2014). The increase of trees on farms in areas that have simultaneously experienced up to $10 \%$ population growth negates the assumption that humans crowd out trees. This trend of increasing tree cover demonstrates that while on-going deforestation for agriculture is a serious issue, there is forest recovery in some regions and there are other possible paradigms for growth (Zomer et al. 2014). A study of TDF patches in Honduras and Mexico also found that forest fallows, fragments, and other anthropogenically disturbed landscape elements can host species diversity levels comparable to forests, as well as species of considerable conservation importance, emphasizing the capacity of some land-use practices to contribute to conservation and restoration initiatives within the agricultural landscape (Gordon 2004). The aforementioned study of live fences in Nicaragua and Costa Rica also demonstrated not only the species richness and ecological benefits of live fences, but also that farmers are already planting and maintaining these trees on their own, without the interference or imposed incentives of projects (Harvey et al. 2005). While some trees remain on agricultural lands, the heterogeneity and origin of these species is not clear, as tree planting in the region has generally promoted only a few exotic timber species 
valued by the international market. Nonetheless, native species are being examined for their production potential (Hall et al. 2010, Wishnie et al. 2007).

Though disturbed and fragmented, the TDF remnants maintain significant biodiversity, as noted above. However, there is reduced diversity in areas of severe anthropogenic disturbance, particularly involving cattle grazing, fire and wood extraction (Gillespie et al. 2000, Willians-Linera and Lorea 2009). Though no plant species has been verified as extinct in the Central American TDF, the level of fragmentation may not retain sufficient genetic diversity to safeguard continued success of populations, and a more disturbed forest will have reductions in productivity, financial value, and commercially-valuable species (Gillespie 2000, Williams-Linera and Lorea 2009).

In planning for reforestation or agroforestry project interventions, native species are largely preferable as they are already adapted to local environmental conditions, provide ecological and economic advantages, are often preferred by local farmers already familiar with them, and are more sustainable than exotic species which may introduce invasive threats and are more costly and time-intensive (Piotto et al. 2004, Montagnini 2005, Griscom et al. 2005, Garen et al. 2009, Degrande et al. 2013). The limited species diversity available to landowners through nurseries restricts private biodiversity conservation and restoration; but local knowledge can be used to determine which tree species are most useful, scarce, or significant to wildlife to increase the efficacy of restoration forestry or agroforestry systems and ensure that species valued by landowners are available in local nurseries (Suarez et al. 2011). Technicians often make species selection decisions, but if local landowner interest is not taken into account, farmers may be discouraged from planting trees and projects may fail (Mekoya et al. 2008). 
The present study focuses on Trinitaria, La Pinta and Pinolillo, pseudonyms for three rural communities in Northwest Nicaragua, where three tree planting projects have been conducted, in different periods from 2000 to 2015, prompted with funding from the Millennium Challenge Corporation, the National Institute for Agricultural Technology (INTA), and grants won through the Peace Corps. While these and other organizations have promoted projects with a variety of objectives, the present study will focus only on tree plantings. Although two other projects were known to have planted trees in Trinitaria, they were small in scale (less than 30 trees planted) and could not be evaluated as a consequence of lack of information. These projects have provided different materials, technical assistance and implementation methods, differences that may have influenced the number of individual trees that survived to be counted in the inventory conducted in the present study and which are compared in Table 3 in Chapter 3. Although the current study was administered too early to evaluate survival rates of the recently conducted Peace Corps projects, germination rates for these species were included as relevant data for future projects.

The Millennium Challenge Corporation (MCC), an independent U.S. government foreign aid agency, completed a Rural Business Development Project from 2006-2011, investing $\$ 51$ million in activities that ranged from founding bee cooperatives to tree planting. The MCC project intended to expand improved agriculture and agribusiness by developing improved production techniques, and improving watershed management by facilitating high value sustainable agriculture and forestry. The project was formulated on the basis of a few assumptions, including a US\$100 annual net income of unimproved manzanas (1 manz.=.704 ha), one to five manzanas (.704-3.52 ha) of average farm area in 
transition, and expenditures of US\$3,728 per farmer. Indicators of interest include number of jobs created and total number of manzanas reforested, measures that were to be evaluated quarterly, though data is not available for specific projects.

In Trinitaria, La Pinta and Pinolillo, the communities relevant to the current study, tree species planted by MCC include cacao (Theobroma cacao) and teak (Tectona grandis). From 2006-2009, nine farmers from these three communities were invited to participate in a series of trainings, including quality testing of milk, veterinary medicine, and cocoa processing, and in 2007 were selected to plant a total of 6,000 cocoa trees for both family consumption and small-scale commercialization for sale in local markets (Cuenta Reto del Milenio 2008). While these same nine farmers were invited to participate in planting teak, only one, the owner of a eucalyptus plantation, planted 10,000 trees. Those that declined the opportunity claimed that the local market could not afford this high-cost timber species, and that once planted they could not eliminate them later due to Ministry of Forestry (INAFOR) restrictions that prohibit the cutting of trees. As one example, the teak saplings were delivered to the plantation owner in May, the beginning of the wet season, and he was responsible for preparing his land, transplanting, and maintaining the trees, and he was visited once by the MCC representative after transplanting. Funding for this project was partially terminated in 2009 as a result of financial mishandling by the Nicaraguan government. The MCC claims to have completed their goal of planting trees on 7,204.03 ha but an independent evaluation, although scheduled, has not been completed (Millennium Challenge Corporation 2010). Study findings suggest that plantations of Tectona grandis are not recommended in the 
region, as they cast dense shade and have fire-prone leaves that can actually be detrimental to native recruitment (Healey et al 2003).

The National Institute of Agricultural Technology (INTA) has also completed several tree restoration projects, including one that was meant to promote madroño (Calycophyllum candidissimum), the national tree of Nicaragua. Although documentation for this project was not available, interviews with project participants revealed some of the details. The species was promoted for multiple uses, including fuel wood, natural medicine and timber, and because it seemed to becoming scarce. The extension office of INTA's method included forming local agricultural groups, and the 24 members of the monthly Trinitaria INTA agricultural group were invited to participate during a regular meeting, where seeds were handed out in small bags but specific planting training was not conducted.

The extension office of INTA conducted several other tree planting projects, including one in 2002 that promoted neem (Azadirachta indica), growing from seed and planting 200 saplings with an agricultural group they formed with members from the three communities. Neem is an introduced species widely promoted for its pest control properties. While neem provides year-round shade, reduces erosion and green leaves are burnt as repellant during mosquito outbreaks, the tree also demonstrates some qualities of an invasive species by acidifying soil (Pankaj et al. 2011). This ability to alter soil conditions creates the perfect conditions for its own abundant seeds to germinate and crowd out other species, while native slow-growing species, possibly of more value to locals are out-competed (Atchinson and Head 2013). The extension office of INTA also claims to have planted 2000 eucalyptus (Eucalyptus camaldulensis) saplings in the year 
2000, another species that lowers soil $\mathrm{pH}$ and makes conditions uninhabitable for other species (Rhoades and Binkley 1996).

Although different from dispersed on-farm tree cover, the plantation in Trinitaria is an important landscape element to include when considering the matrix-patch-corridor structure of this area, particularly with regards to ecosystem services provided by such a large forested area. The 140.8 ha diversified farm features 18 ha of crop cultivation (sugarcane), over 55 ha in pasture, 7 ha of teak as previously mentioned, and 60 ha of eucalyptus (Eucalyptus camaldulensis) planted by the Monte Rosa sugar mill in 1990 after the soil was no longer capable of producing sugar. The sugar mill continues this practice today, planting trees, all monocultures of an introduced species, on exhausted soil in order to justify continued sugarcane expansion to the International Finance Corporation (IFC), claiming, surprisingly, increased biodiversity and reduction in fossil fuel use (as they burn the eucalyptus in its boilers) (IFC 2007, Pantaleon 2010). While the densely wooded area of exotic species may provide some ecosystem services in the form of erosion prevention, increased soil permeability and carbon sequestration, a greater diversity of species would be preserved in the landscape by plantations of native timber species rather than monospecific, alien species (Current and Scherr 1995, Käffer et al. 2009, Ardila Rios et al. 2015). Eucalyptus is also a high water consumption species and a known aggressive invader, a factor that the neighbors with wells in dry Chinandega anecdotally do not appreciate, though claims of lower water tables have not been locally evaluated (Dzikiti et al. 2016). Monte Rosa planted an estimated 180,000 saplings before a lawsuit reverted control to the owner. 
Enrichment tree plantings can encourage diversity and introduce native species that may be locally extinct to restore important ecosystem or economic functions, while improving soil conditions, improving seed dispersal, ameliorating harsh climate conditions, and accelerating forest succession (Griscom and Ashton 2011). In order to increase stakeholder benefits, these trees should also provide some economic value, and should focus on late-successional species that might not colonize unassisted and that also provide important ecosystem or economic benefits, including Calycophyllum candidisimum, Ceiba pentandra, Anacardium excelsum and Enterolobium cyclocarpum (Griscom and Ashton 2011). Once these species are established and can provide shade, desiccation-prone species such as Manilkara chicle and Brosimum alicastrum can be promoted. In consideration of the advantages of native species, research demonstrates that while three local species, Tabebuia rosea, Enterolobium cyclocarpum (Jacq.), and Cedrela odorata, have been promoted to landowners as easily seeded with well-known management techniques, there are many other local species that can provide numerous benefits to both communities and biodiversity conservation (Griscom et al. 2005, Suarez et al. 2012).

Swietenia humilis, Cordia alliodora, Gliricidia sepium, are markedly important species locally as well as internationally, and Pachira quinata Jacq, Anacardum excelsum, Guazuma ulmifolia are also valued for multiple uses, including wood for construction and furniture, firewood, food for livestock, and physical attributes such as shade and aesthetics (Galicia 2008, Garen et al. 2011). Tabebuia crysantha is also valued locally and listed as endangered but is not available in local nurseries, and several studies 
have compiled lists of species that demonstrate cultural and environmental utility (Williams-Linera and Lorea 2009, Griscom et al. 2005, Suarez et al. 2012).

The most successful tree-planting interventions combine technical assistance with minimal in-kind material inputs, as cash or other incentive programs are often plagued by dependency, lack of continuity and unwillingness to participate if assistance is withdrawn (Current and Scherr 1995). Policy makers should favor these kinds of self-financing or minimal in-kind incentives family nurseries. While they plant trees at a slower rate, farmers gradually expand their plantings on their own once they are trained and benefits become apparent, reducing the need for government and technical assistance and creating more developed self-sufficiency (Current and Scherr 1995).

Studies suggest that aside from some species of specific concern, regional strategies may be developed that will more effectively promote tree restoration, rather than drafting individual plans for different landscapes, a larger-scale approach may incorporate both migratory bird species as well as landscape features and different landuse areas (Mendoza et al. 2014). However, within the larger landscape framework, sitespecific projects should be included in order to incorporate differing anthropogenic preferences, needs and motivations as they vary across landscapes (Garen et al. 2011). Trees on farms have the potential to restore valuable ecosystem services lost or reduced in agricultural conversion, but restoration plans must account for the social dynamics of the landscape in deciding which species to encourage (Griscom and Ashton 2011). Rainfall and seasons, dry season water availability and access, soil quality and other biophysical characteristics should especially be considered in the TDF region. In order to assess the farmer motivations in tree management and participation of some past tree 
planting projects, three study sites in the tropical dry forest region of Nicaragua will be analyzed.

The present study was undertaken as part of the Master's International Program (MIP) with the Peace Corps, during which original thesis research was conducted while completing volunteer service. After completing language training, I was placed in the community of Trinitaria, Chinandega in August 2012, where I lived with my host family until I finished service in August 2015. As a Sustainable Agriculture and Food Security volunteer, I conducted a community needs assessment and completed several projects, including: forming four community banks, writing and teaching sustainable agriculture curriculum, conducting improved patio management and agroforestry practices trainings in coordination with the Ministry of Agriculture extension technician, and establishing over 100 private and communal tree nurseries, coordinating the training, procurement of materials and labor, and planting over 50,000 native trees throughout seven communities. To complete my MIP project, I designed and completed a survey and tree inventory in three of these communities, quantifying the species and diversity of local trees, investigating farmers' use and knowledge of their on-farm dispersed tree cover, and analyzing the efficacy of the aforementioned reforestation projects in order to improve the effectiveness of future tree-planting projects. The tree-planting projects I conducted as a volunteer are included in this study.

In designing my tree-planting project, I attempted to apply the lessons learned from the prior local projects and my agroforestry research. A group of 32 members from the three communities was formed, and a Participatory Analysis for Community Action (PACA) was conducted, an evaluation that includes community mapping, seasonal 
calendar, and a needs assessment from which the community members themselves select priorities. One of the first projects selected was a communal tree nursery, and participants each year selected the species they wanted to plant. Interestingly, species formerly promoted, including eucalyptus, teak and melina were specifically rejected as too water intensive. With the exception of moringa (Moringa oleifera), which was being promoted by the media in Nicaragua as a powerful panacea, all species requested were native. With the exception of Guazuma ulmifolia, a species requested only by livestock owners, all were also requested for timber, demonstrating both and awareness of environmental restrictions on non-native species, and the real demand for native hardwood trees.

Each year, all participants received three training sessions from the Ministry of Forestry (INAFOR) extension technician, who informed participants on different species necessities and conducted a practical, which included soil preparation, seed handling, and nursery maintenance. Materials used include small black nursery bags, calcium oxide or ashes to avoid fungus, and rice husks or sawdust to prevent soil clumping, all of which were locally available and inexpensive or free. Each participant was then given the amount of bags and seeds they requested, and they were responsible for their own land preparation, seeding, and maintenance. They received at least three home visits by the Peace Corps volunteer to help reduce problems and gather information, which was time consuming but was conducted in an effort to improve communication and tree planting success. The first year seeds were donated by INAFOR, but did not arrive until late March, very late in the planting year as many species should have at least 4-5 months in the nursery before being transplanted at the beginning of the rainy season in May. To avoid this problem, seeds were purchased in subsequent years (except for Moringa 
oleifera and Cordia alliodora, which were collected from local trees) from SEITropic seed bank in January, with half of the funding provided by stakeholders and half from a Peace Corps grant. In 2014 and 2015, cortez (Tabebuia chrysantha) was also requested but a guaranteed seed source could not be found.

Germination was calculated on the first home visit, after which participants reseeded those that did not germinate. The smallest seeds, madroño and Cedrela odorataa, showed the lowest germination rates, with the exception of Cordia alliodora, which demonstrated insect damage. Participants disappointed in the performance of Cordia alliodora did not request the species for one year until the 2015 planting season, where seeds were harvested locally and demonstrated only a slight increase in germination rate. Participants discussed the difficulty of working with the smaller seeds and the fickleness of the weather in waiting to transplant.

In the tropical dry region of Nicaragua, farmers can usually count on a burst of rain in late April/ early May, the ideal time to plant crops and transplant saplings. From 2013-2015, the three years the researcher conducted these projects, the rainy season was less predictable and less prolific, extending a drought compounded by El Niño. Warming temperatures, delays in the start of the rainy season, less frequent rainfall and crop losses in Nicaragua, trends that are caused in part by loss of forest cover, are expected to continue under climate change scenarios, adding urgency to reforestation projects (Gourdji et al. 2015). Increasing the number and diversity of trees and their connectivity could help increase social and ecological resilience in the face of climate change, allowing for population adjustments, range shifts, and other natural adaptations to the changing environment (Millar et al. 2007, Dymond et al. 2014). 


\section{Study Site and Methods}

In this section, greater detail will be given study site and research methods, to be summarized in Chapter 3. The study area includes 3 communities located in the tropical dry forest region of northwest Nicaragua, chosen opportunistically, as the researcher lived in Trinitaria and worked in the adjacent La Pinta and Pinolillo during her Peace Corps service. The three areas are each recognized as communities, the lowest level of government administration in Nicaragua (though territory size is not clearly delineated) and are demographically representative of the region as small rural villages with populations of less than 1,000. Most recent (unpublished) Ministry of Health (MINSA) census data indicates populations of 630,323 , and 169, respectively, and the government considers the region "severely poor" (CIFRAS 2008).

Trinitaria is a rural community that runs along a paved highway, while the other two communities are only accessible by dirt paths. All three communities are without running water, and while Trinitaria and La Pinta have been connected to the electric grid, Pinolillo remains without power. Daily primary school and Saturday secondary school are available in Trinitaria to students of all three communities, and there is a health clinic in Trinitaria that is open three days a week. According to the MINSA health clinic data, $63 \%$ of residents receive some of their family income from the local sugar mill. Although some of the landholdings are too small to be considered farms, they can still be thought of as home gardens, and these plot sizes are representative of much of the country's land division. In Nicaragua, $9 \%$ of landowners own $56 \%$ of the land, while $61 \%$ of farmers own only $9 \%$ of the land area, with an additional $38 \%$ of the rural population struggling and landless (USAID 2010). As small landholders and landless tenants become more 
common, their preferences and tree management decisions should be considered, and they should be encouraged to participate in agroforestry practices to diversify their income and increase their food security in the spaces available to them, even if only in small home gardens. The three communities cover a combined 528 ha, forming a patchwork of agricultural fields, pasture, and roads laced together by riparian corridors, with the different landscape elements demonstrated in the Google Earth image below.

\section{Figure 1. Aerial Map of Three Study Communities (Source: Google Earth Pro)}

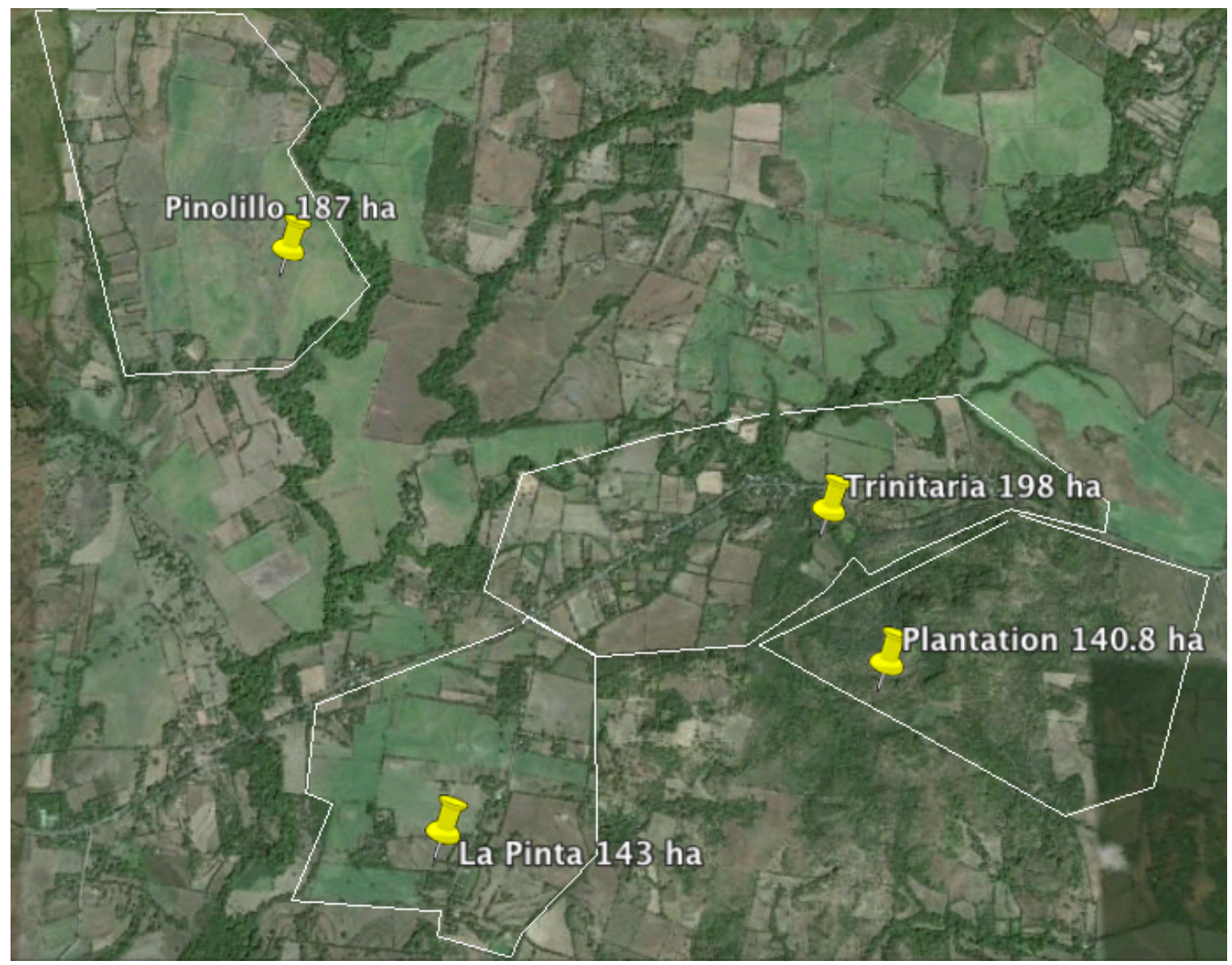

Bright green fields of highly fertilized sugarcane pattern the agricultural matrix

shown in Figure 1, intermingled with brown tracts marking already burnt sugarcane or peanuts, and dark green ribbons of riparian corridors that mark tributary streams that join 
to form the river. Thinner corridors of live fences are interspersed amongst the fields, and with the exception of the eucalyptus plantation on the southeast border of Trinitaria, very few forest patches are evident. Tree cover can also be found on private property in the form of dispersed trees in pasture, windbreaks, and denser plantings of fruit trees in patios. The landscape underwent a major wave of deforestation, stripped first for timber infamously then for cattle and cotton from the 1930's through the 1970's, with the earliest satellite imagery validating that the landscape was already heavily deforested by the late 1960 s, in many places stripped down to the banks of the rivers. Thus, the trees covering the riparian corridor are apparently a recovering secondary forest, demonstrating a partial landscape recovery (Google Earth 1969, Griscom and Ashton 2011). These forest remnants, constituting corridors, are crucial in rural landscapes in improving stream water quality as well as restoring ecosystem functions, particularly in areas scarred by intense agriculture, in this case former cotton and current sugarcane production (Tanaka et al 2015). However, there is currently increased agricultural land use pressure because of the expansion of two export crops. Nicaragua increased it's sugarcane planted area in 2013 by $13 \%$ to 67,128 ha, a number expected to surge another $20 \%$ by this year (2016), while peanut plantations occupy 42,253 ha, $82 \%$ of which is concentrated in the west (USDA 2013). These production increases demonstrate a dynamic that may negatively transform the landscape matrix seen above, as the highly mechanized cultivation of these crops compacts soil, and reduces soil fertility and productivity, adding urgency to increasing tree cover in the other elements of the landscape of Northwest Nicaragua (Naranjo de la F. et al. 2006, de Oliveira Cardoso et al. 2012). 
The study site provides an excellent candidate for enrichment plantings, as it is characterized by areas that have lost site productivity, particularly lands that have been repeatedly burned, over-grazed, planted with exotic grasses, subjected to intensely mechanized cultivation methods, or are sparsely populated by parent tree seed sources (Griscom and Ashton 2011). While the forested riparian corridors that exist within this landscape provide a resource for passive restoration, facilitating relatively diverse second growth forests, the diversity of species composition of pasture trees and live fences can be promoted to encourage further diversity restoration.

In order to evaluate factors significant in informing farmer's decisions about this on-farm tree cover, a household survey was written to collect information about demographic details including age, education level, and family size, as well as social capital, economic, and land-use elements (Sood and Mitchell 2009, Haglund et al. 2011, Degrande 2013). The survey was translated to Spanish, and interviews were conducted face-to-face with heads of households from June to August 2015. Participants were asked to share the experiences of past tree planting projects (if any), including project objective, methodology, and species selection. A tree transect was conducted evaluating all woody vegetation with diameter at breast height ( $\mathrm{DBH}$ or $1.3 \mathrm{~m}$.) $>10 \mathrm{~cm}$. to evaluate the survival rates of tree plantings, as well as the quantity and variety of tree cover in the area (Nascimiento and Laurance 2002, Rolim et al. 2005, Bastien-Henn et al. 2010). Participants were asked to describe their motivations in planting, maintaining and/or removing these species, to determine their values or uses (Garen et al. 2011). Participants were also asked to estimate the amount of weekly fuel wood use and its source, as an 
estimated $70 \%$ of Nicaraguans cook with fuel wood and it is considered a major driver of deforestation (Sabogal 1992).

To ensure a representative sample, the respective 93,42 and 26 properties in Trinitaria (T), La Pinta (LP) and Pinolillo (P), were stratified into small (0-0.6 hectares), medium (0.7-2.5 hectares) and large plots (2.51-15 hectares). After stratification, every fourth property was selected to participate in the survey and tree inventory in each community, to include 7 from $\mathrm{P}, 11$ from LP, and 26 surveys in T for a $25 \%$ sample size of each village. The tree inventory also stratified and included every second property, with 20 properties from $\mathrm{P}, 30$ from LP, and 60 from $\mathrm{T}$ for a $>60 \%$ sample of each community. One outlier, the 140.8 ha eucalyptus plantation mentioned above, is not included in the calculations but is highlighted as a case study. The inventory counted all trees with a diameter of $\geq 10 \mathrm{~cm}$, from which an estimated tree density per hectare was extrapolated per property.

Five random samples of 10 sq. meters of the local riparian area were included to establish a baseline forest density and to understand species diversity in a spontaneously recovering dry tropical forest. Similarly, ten $10 \mathrm{~m}^{2}$ samples were conducted within the eucalyptus plantation to evaluate stem density and investigate claims that eucalyptus plantations encourage native species diversity. Four informal interviews were also conducted with local loggers to determine species being cut, use, adherence to the permit process and profitability of logging. These interviews were made under the assurance of anonymity, as many of the reported activities are illegal. 
As noted, Chapter 3 will summarize the most salient aspects of the literature review, and introduce some additional literature relevant to my results, methods and site, and present the research results and discussion in a peer-reviewed journal format. 


\title{
CHAPTER III \\ JOURNAL ARTICLE
}

\begin{abstract}
The conversion of forest to agricultural lands is well documented, particularly in the tropical dry forest of Central America, which maintains only $1.7 \%$ of its former territory. Tree loss has economic, ecologic, hydrologic and climatic ramifications, but studies are demonstrating that the farms or forest dichotomy is a false framework that fails to recognize the possibilities of agroforestry. Agroforestry incorporates trees into agricultural lands through practices such as live fences, windbreaks, dispersed trees and woodlots, enhancing connectivity in the patch-corridor-matrix. Many of these practices are already applied by farmers in the northwestern tropical dry region of Nicaragua, and projects by the Millennium Challenge Corporation, the Nicaraguan Ministry of Agriculture, and the Peace Corps have attempted further plantings to ameliorate past forest conversion damage.
\end{abstract}

Through 44 social surveys and a 217.11 ha inventory of current tree cover in three communities in northwest Nicaragua, my study attempted to evaluate the trees remaining from past tree plantings and understand the factors influencing landholders in their tree management decisions. Factors influential in tree planting participation appear to be agroforestry group participation, property size, hectares planted and land dedicated to pasture. Tree density per plot seems to be influenced by property size. Of the 88 species found in the private property inventory, $66.68 \%$ were native, 70 were valued for multiple uses, and several native species showed germination rates $>70 \%$, including Swintenia humilis, Guazuma ulmifolia, Glirincidia sepium, Ceiba pentandra and Tabebuia rosea. 
These species present great potential for future reforestation projects in the tropical dry forest region as natives already adapted to the climate that provide habitat and ecosystem services, as well as social and economic benefits to landholders.

\section{Literature Review}

The Central American tropical dry forest (TDF) hosts high endemic species richness and biological diversity comparable to the tropical rainforest. Although less renowned, is considered one of the world's most endangered ecosystems, covering only $1.7 \%$ of its former range and losing territory mostly to agricultural conversion (Janzen 1988, Vieira and Scariot 2006, Harvey et al. 2008, Calvo-Alvarado 2008, Galicia et al. 2008, Griscom and Ashton 2011). The remaining fragments demonstrate such detrimental edge effects as exotic or invasive species, decreasing plant recruitment and increase in tree mortality rate, especially because of changes in the microclimate. However, perhaps as a function of its adaptability to frequent and seasonal natural disturbances, the TDF

demonstrates a resilience that may allow it to recover slowly, principally as a result of agricultural abandonment in some parts of its range, and depending on species reproduction, seasonality, and plant growth rate (Portillo-Quintero et al. 2013). The high regeneration potential is demonstrated in the state of Guerrero, Mexico, as well as several regions throughout Central America, where secondary TDF is expanding and is characterized not by fragments, but by increasing continuity and high connectivity (Galicia et al 2008, Griscom and Ashton 2011).

The TDF in Central America is marked by distinct wet and dry seasons, with little to no precipitation falling from November to May. A 0.01 ha of intact TDF hosts from 7.1-12 different species of trees and shrubs, with particular representation of species form 
the Fabaceae, Bignoniaceae, Sapindaceae, Rubiaceae, and Euphorbiaceae, families (Gillespie et al. 2000). Some of the most abundant species include Heliathinae spp, Cordia alliodora, Guazuma ulmifolia, Tabebuia spp., Enterolobium cyclocarpum, Pachira quinata, Bursera simaruba, Gliricidia sepium, Diospyros nicaraguensis, E. salamensis, Brosimum alicastrum, Casearia corymbosa, Eugenia guatemalensis, Calcophyllum candidissimum, and Bombascopsis quinata, among others (Gillespie et al 2000, Tarrasón et al. 2010, Griscom and Ashton 2011). While diversity is relatively high, average tree density in Central American TDF is much lower than other neotropical forests, ranging from 42-62 trees $\mathrm{DBH} \geq 10 \mathrm{~cm}$ per $1000 \mathrm{~m}^{2}$ (Gillespie et al. 2000).

Despite lower densities, there are other signs that agricultural conversion is now being reversed and that tree cover is expanding modestly. Ninety-six percent of the agricultural land in Central America has retained tree cover of $>10 \%$, representing an increase of $1.6 \%$ from 2000 , with $47 \%$ showing substantial tree cover of $>30 \%$ (Zomer et al. 2014). This increase of trees on farms in areas that have simultaneously experienced up to $10 \%$ population growth negates the assumption that humans crowd out trees, demonstrating that while on-going deforestation for agriculture is a serious issue, there is forest recovery in some regions and there are other possible paradigms for growth (Zomer et al. 2014). Studies of TDF patches in Honduras and Mexico, live fences in Nicaragua and Costa Rica, and remnant trees in pasture in Costa Rica, have found that forest fallows, fragments, and other anthropogenically-disturbed landscape elements can host species diversity levels comparable to forests, as well as species of considerable conservation importance, emphasizing the capacity of some land-use practices to contribute to conservation and restoration initiatives within the agricultural landscape 
(Gordon 2004, Harvey et al. 2005, Sandor and Chazdon 2014). The aforementioned study of live fences in Nicaragua and Costa Rica also demonstrated not only the species richness and ecological benefits of live fences, but also that farmers are already planting and maintaining these trees on their own, without the interference or imposed incentives of projects (Harvey et al. 2005). My study examines the dynamics of such a landscape, where farmer-motivated plantings, projects and spontaneous recovery of a riparian forest have created a landscape with a modest amount of tree cover.

In the present study, I will review trees on farm, riparian forests and plantations as landscape elements in an agricultural matrix in the tropical dry forest region of Northwest Nicaragua, as well as farmers' preferences, tree management practices, and suggestions for reforestation initiatives.

Although studies of species composition and forest structure indicate a strong degradation of forest remnants in Nicaragua in particular, they are still seen a valuable resources by local landholders and thereby offer opportunities to be preserved (Tarrason et al. 2010).

In order to better understand the dynamic transitions and the current state of the tropical dry forest, we must look beyond forest fragments to see the trees in the wider landscape. While some of these trees remain in dense patches and riparian forests, many are scattered throughout private lands as dispersed trees in pasture, windbreaks, and live fences, lacing the different landscape elements together to form an agricultural matrix with varying degrees of connectivity. Though they do not host the density of a forest habitat, these trees on farms, often forming agroforestry systems, do provide some social, economic and environmental benefits. 
Trees on farms have a positive effect on bird and insect assemblages, and are consistently used by a wide variety of species, serving as foraging sites, additional habitat, and resting perches between fragmented ecosystems (Mendoza et al. 2014). Additionally, trees increase hydrologic services in pastures, improving soil permeation and infiltrability and reducing surface runoff, services essential to the recharge and maintenance of ground-water systems (Grinevski and Novoselova 2011, Benegas et al. 2014). Trees also mitigate flooding, increase evapotranspiration and may even influence rainfall patterns and increase water availability across regions, even extending wet season storage and flow into the dry season (Malmer et al. 2010, Ellison et al. 2012).

Woody vegetation also increases carbon sequestration when integrated into pastures (Haile et al. 2010, Andrade et al. 2008), and certain species may be used to boost soil fertility through organic matter and nitrogen fixation, mitigating the adverse results of land degeneration (Wishnie 2007). Many landholder needs, including fuel wood, timber, shade, fodder, fruit, and natural medicines may also be addressed by increasing tree cover on their property, improving rural livelihoods and well-being while providing many of the aforementioned ecological services (Barrance 2003, Hall 2010, Place et al. 2011). Tree adoption has been positively linked to income gains as well as greater species diversity on farms, providing both social and environmental benefits (Haglund et al. 2011). Smallholders who work $<2$ ha land, the majority of the farms in the study area, and represent some $90 \%$ of global farmers can particularly benefit from an increase in resilience through diversified tree plantings (World Bank 2007). As small, diversified farms have demonstrably proven more productive per area than high-input monocultures, and because smallholder systems form the foundation of global food security for the rural 
poor, an increase in on-farm tree cover and effective tree management strategies can result in diversified income and increased resilience to intensifying droughts linked to climate change, as well as pests, or market failures for some of the most vulnerable rural populations (Keating et al. 2010, Horlings and Marsden 2011, Tschamtke et al. 2012).

Though studies agree that trees provide essential services, these functions may be perceived differently among stakeholders, and the differing priorities of landowners on acceptable types and quantities of trees must be considered in ensuring integration and sustainability of landscape management (Meijaard 2013, Welsch et al. 2014). Farmers engaged in agroforestry practices are sometimes willing to accept some crop production loss in return for valuable tree products, including fruit and fodder (Hocking et al. 1997). In contrast, trees may sometimes be considered incompatible with agriculture, as competition for sunlight, and deforestation sometimes acceptable on the small-scale as improving local welfare (Benjamin et al. 2008, Meijaard et al. 2013).

Studies assessing the variables that condition tree adoption have highlighted several factors as influential, including gender of head of household, landholding size, soil type, market distance, family size and age distribution, (related to labor availability), annual income, irrigation availability, education level, possibly even religion (Haglund et al. 2011, Degrande et al. 2013, Ashraf et al. 2015). Accessibility and tenure of land may also influence management decisions, as well as benefits (both perceived and real), and types and availability of trees (Malla 2012). While these are underlying variables that condition decisions to participate or not participate in tree adoption, they are often outside of the consciousness of the farmer. 
In contrast, actual behavior can be used to analyze and forecast types and reasons trees are planted through stated and revealed preference. Stated preference (SP) refers to individual respondents' assertions about their preferences, and is demonstrated in the reasons farmers claim to plant or maintain trees. The more conventional revealed preference (RP) valuation relies on the use of some resource in the past and/or current conditions, in this case noting what trees were actually planted (Whitehead et al. 2008). While these terms are usually reserved for economic evaluation of willingness to pay, they are applicable here for future tree planting initiatives. Trees planted by the stakeholders at their own expense highlight revealed preference, while tree planting projects that do not investigate or collaborate with these preferences fail to capitalize and connect with local circumstances.

Local stakeholders use and value trees for food, medicine, fuel wood, non-timber forest products, water services, conservation of biodiversity, timber, climate moderation, and even religious reasons, with priorities varying over regions and affected by water availability, livestock and crop cultivation (Pfund 2011, Garen et al. 2011). These regionally specific factors, as well as an understanding of existing policies, must be weighed to understand how the rational farmer will evaluate the cost-benefit ratio of tree adoption (Foundjem-Tita et al. 2013).

While several studies have been conducted on farmer preferences of tree species (Garen et al. 2011), as well as the presence of natural regeneration of trees and the alternate protection or cutting of certain species (Harvey 2000, Harvey et al. 2011, Griscom and Ashton 2011), few have compared these two forms of tree introduction in a landscape (Barrance et al. 2003). In addition, the literature omits comparing these sources 
to project-promoted species in order to determine whether or not tree-planting efforts align with stakeholder preferences, or promote species that may have stakeholder value but are scarce or not naturally regenerating. The present study examines the full range of tree management practices, evaluating quantity of naturally regenerated volunteers, stakeholder- and project-preferred trees, ranking and comparing the stated uses and values of these species. The literature suggests that factors influencing tree planting project adoption include regional uses and values, growth rates, management decisions, expectations, and continuity of extension efforts (Garen et al. 2009, Hall et al. 2011).

Because studies stress the importance of regionally specific social norms and customs to the success or failure of tree planting projects, information is needed on what influences the success of these projects in this region, and whether or not they are even necessary. This study will attempt to trace the sources of trees in the agricultural landscape and compare numbers grown from natural regeneration, projects, and the stakeholders themselves. While sources of trees in a landscape are important, and though appropriate levels of tree cover will vary across regions and should not be prescribed, tree density within a landscape must also be considered (Zomer et al. 2014).

While a study in Kenya demonstrated that average on farm tree density reached 702 trees per hectare in a formerly degraded landscape (Langkeek et al. 2005), most studies focus on the occurrence of trees found in individual landscape elements, including windbreaks (Harvey 2000), riparian forests (Griscom et al. 2011), and dispersed trees in pasture (Hervey and Haber 1999, Harvey et al. 2011). The present study attempts to address the gap in the literature, taking a landscape approach to looking at the current state of tree cover in a heavily disturbed TDF landscape and how greater tree cover is 
apparently emerging from a combination of passive recovery of riparian forests, farmer decisions to plant more trees, including one plantation, and the more minor role played by projects that specifically promote tree planting. The study also examines the potential for increasing tree density throughout all elements in heavily degraded agricultural landscape mosaics. The studied landscape may have been almost completely deforested in the 1960 's, as a consequence of the cotton and cattle boom. Deforestation pressures continue because of the current regional emphasis on crops destined for export, especially sugarcane, peanuts and plantains. Although sustainable agriculture has been limited, a degree of forest recovery has taken place in recent decades, and connectivity has increased within the patch-corridor-matrix. There is now a recovering riparian forest, live fences planted because of farmers' needs and preferences, and a eucalyptus plantation, as well as some nominal tree planting initiatives. I will present data on the factors that influenced the emergence of trees in this landscape, typical of highly degraded areas in northwest Nicaragua, analyzing general land uses, tree density and diversity on farms, stated stakeholder uses and the revealed preferences evident in the distribution of voluntary, farmer planted and project promoted species, and variables that condition project participation in tree planting projects.

\section{Study Site and Methods}

The study area includes 3 communities located in the TDF region of northwest Nicaragua, chosen opportunistically, as the researcher lived in Trinitaria (T) and worked in the adjacent La Pinta (LP) and Pinolillo (P) during her Peace Corps service. In order to protect the privacy of participants, these sites have been given pseudonyms as some illegal activity is reported. The three settlements are each recognized as communities, the 
lowest level of government administration in Nicaragua (though territory boundaries are not clearly delineated) and are demographically representative of the region as small rural villages with populations of less than 1,000. Most recent (unpublished) Ministry of Health (MINSA) census data indicates populations of 630,323, and 169, respectively, and the government considers the region "severely poor" (CIFRAS 2008).

Trinitaria is a rural community that runs along a paved highway, while the other two communities are only accessible by dirt paths. While Trinitaria and La Pinta have been connected to the electric grid, all three are without running water. Daily primary school and Saturday secondary school are available in Trinitaria, to students of all three communities, as well as a thrice-weekly health clinic. According to the MINSA health clinic data, $63 \%$ of residents receive some of their family income from the local sugar mill. Although some of the landholdings are too small to be considered farms, this is representative of the rest of the country's land division. In Nicaragua, 9\% of landowners own $56 \%$ of the land, while $61 \%$ of farmers own only $9 \%$ of the land area, with an additional $38 \%$ of the rural population struggling and landless (USAID 2010). As small landholders and landless tenants become more common, their preferences and tree management decisions should be considered, and they should be encouraged to participate in agroforestry practices to diversify their income and increase their food security in the spaces available to them, even if only in small home gardens. The three communities cover a combined 528 ha, forming a patchwork of agricultural fields, pasture, and roads laced together by riparian corridors, with the different landscape elements demonstrated in the Google Earth image below. 


\section{Figure 1. Aerial Map of Three Communities (Google Earth Pro)}

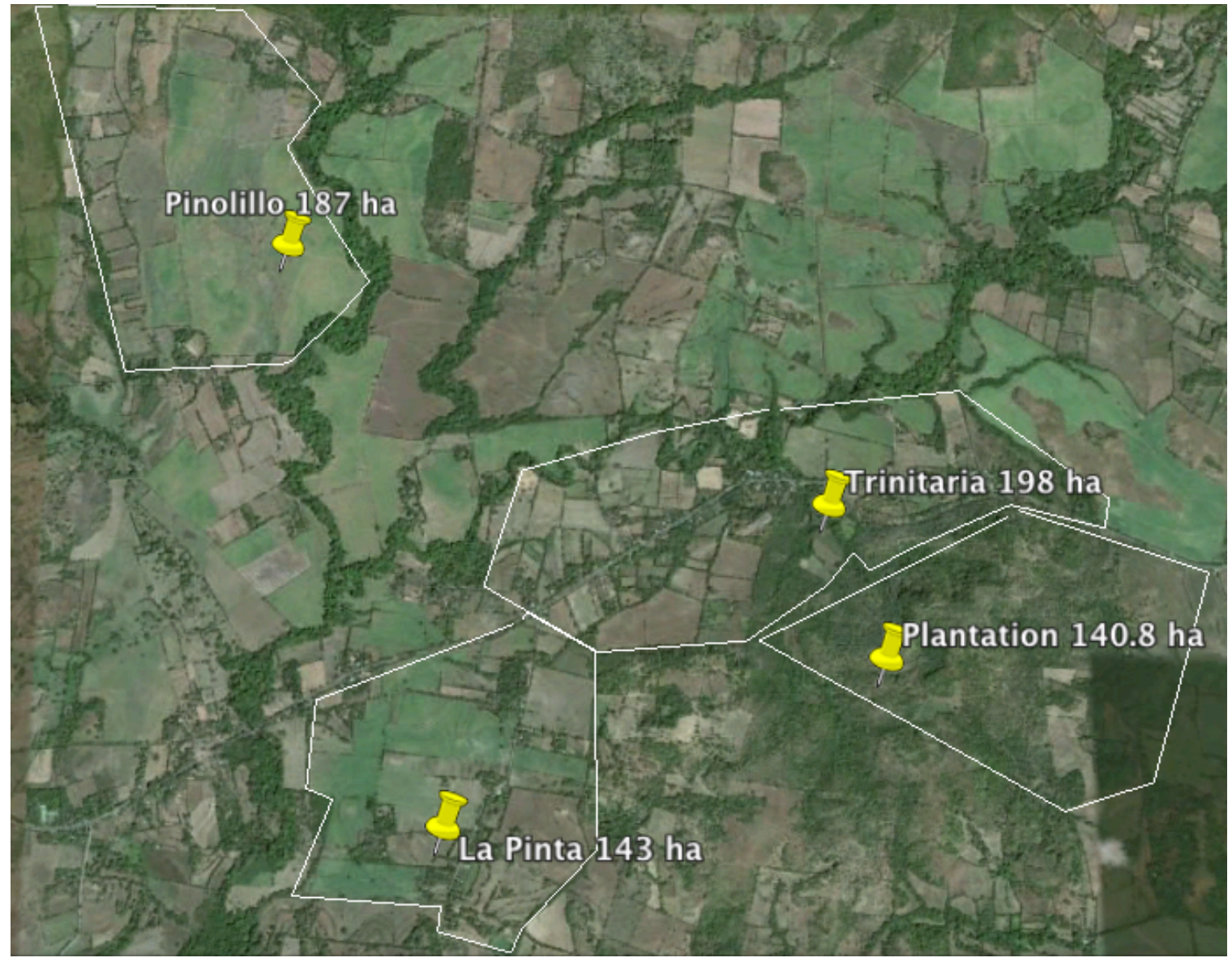

Bright green fields of highly fertilized sugarcane pattern the agricultural matrix seen here, with the brown tracts representing already burnt sugarcane or peanuts, and woven with dark green ribbons of riparian corridors that mark tributary streams that join to form the river. Thinner corridors of live fences are interspersed amongst the fields, and with the exception of the eucalyptus plantation on the southeast border of Trinitaria, very few forest patches are evident. Tree cover can also be found on farms in the form of dispersed trees in pasture, windbreaks, and denser plantings of mostly fruit trees in patios. Because the landscape was stripped first for timber and then for cattle and cotton from the 1930's through the 1970's, with the earliest satellite imagery validating the outcome 
of almost complete deforestation, the trees covering the riparian corridor are probably a recovering secondary forest, demonstrating a degree of forest recovery in the landscape (Google Earth 1969, Griscom and Ashton 2011). Riparian forests are crucial in rural landscapes in improving stream water quality as well as restoring ecosystem functions, particularly in areas scarred by intense sugarcane production (Tanaka et al 2015). The riparian forest is considered a common property available to the public through some unpaved roads, and some farms border riparian area, though they are prohibited from cultivating or clearing the land within 50 meters of the river bank. Extraction of timber or wildlife is prohibited.

To evaluate variables that influence farmer's decisions about this on-farm tree cover, a household survey was developed to collect data on age, education level, and family size, as well as social capital, economic, and land-use elements (Sood and Mitchell 2009, Haglund et al. 2011, Degrande 2013). Participants were asked to share the experiences of past tree planting projects (if any), including project objective, methodology, and species selection. Participants were also asked to estimate the amount of weekly fuel wood use and its source, as an estimated $70 \%$ of Nicaraguans cook with fuel wood and it is considered a major driver of deforestation (Sabogal 1992). The survey was translated to Spanish, pre-tested on five households, and then interviews were conducted face-to-face with heads of households from June to August 2015.

To ensure a representative sample, the 93, 42 and 26 households in Trinitaria (T), La Pinta (LP) and Pinolillo (P) respectively, were stratified into those with small (0-0.6 hectares), medium (0.7-2.5 hectares) and large plots (2.51-15 hectares). Every fourth 
property was then selected to participate in the survey in each community, yielding 7 from $\mathrm{P}, 11$ from LP, and 26 surveys in $\mathrm{T}$ for a $25 \%$ sample size of each village.

A tree inventory was also conducted to evaluate the species planted through farmer preferences and by tree planting projects, as well as the quantity and species diversity of tree cover in the area (Nascimiento and Laurance 2002, Rolim et al. 2005, Bastien-Henn et al. 2010). Properties were also stratified to include 20 properties from P, 30 from La P, and 60 from TV for a $>60 \%$ sample of each community. The inventory counted all woody vegetation with a diameter at breast height $(\mathrm{DBH}) \geq 10 \mathrm{~cm}$, from which an estimated tree density per hectare was calculated per property. Participants were asked to describe their preferences in planting, maintaining and/or removing these species, to determine their values or uses (Garen et al. 2011). One outlier, the 140.8 ha eucalyptus plantation mentioned above, is not included in the calculations but is discussed as an important tree cover element of the landscape.

Five random samples of $10 \mathrm{sq}$. meters of the riparian area were included to establish a baseline forest density from a more natural TDF and to characterize species diversity. Similarly, ten $10 \mathrm{~m}^{2}$ samples were conducted within the eucalyptus plantation to evaluate stem density and species diversity, to evaluate the claim by the sugar mill of promoting biodiversity. Four informal interviews were conducted with local loggers to determine species being cut and their uses. These interviews were made under the assurance of anonymity, as permits had not been acquired for the logging.

\section{Results}

As mentioned, the land use shows a mosaic dominated by agriculture, with trees distributed throughout the matrix as windbreaks, patio plantings and dispersed trees in 
pasture, and dense patches of trees generally restricted to riparian corridors and the exotic plantation. First, with respect to the survey, the 44 landowners who participated in the survey collectively own 154.11 ha. The territory surveyed includes 13 large landholdings of 2.51-15 ha, 9 medium landholdings of 0.7-2.5 ha, and 22 small landholdings of 0.6 or less ha, with an overall average property size of 3.5 ha. Of the 154.11 ha of the survey, 89.056 ha are used to pasture 371 cattle and 17 sheep, and 53.94 ha are planted annually with crops. Of these figures, $95.26 \%$ of the pasture, $88.14 \%$ of the livestock, and $87.5 \%$ of the cropland and is concentrated in the 13 large landholdings. The land includes 34.48 ha planted with sugarcane and the remaining 19.5 ha planted with (in order of quantity): peanuts, corn, rice, sorghum, beans and others. While the use of live fences and windbreaks are common with some of these crops, the mechanization and annual burning of sugarcane discourages tree growth. Live fences are also common along pasture land, which also feature some dispersed tree cover.

The tree inventory included 110 properties covering 217.19 ha, counting all trees with $\mathrm{DBH}>10 \mathrm{~cm}$. The inventory was used to calculate average tree density per hectare per property, in order to help evaluate quantity and species diversity of tree cover on farms in the study communities. Small properties (0-0.06 ha) demonstrated a density of 302.4 trees per ha (tph), while medium plots $(0.7-2.5$ ha) hosted 116.4 tph, and large properties (2.51-15 ha) held an average 46.1 tph. As demonstrated in Figure 1, a linear regression model of the inventory found that property size is negatively correlated to tree density, with a significance of .013 and a beta co-efficient of -.27 . Other factors that were tested, including dry season water availability, tenancy, and years the property have been owned, were found to be not significant, perhaps due to a small sample size. 


\section{Figure 2: Normal P-P Plot of Regression Standardized Residual}

Dependent Variable - Tree Density

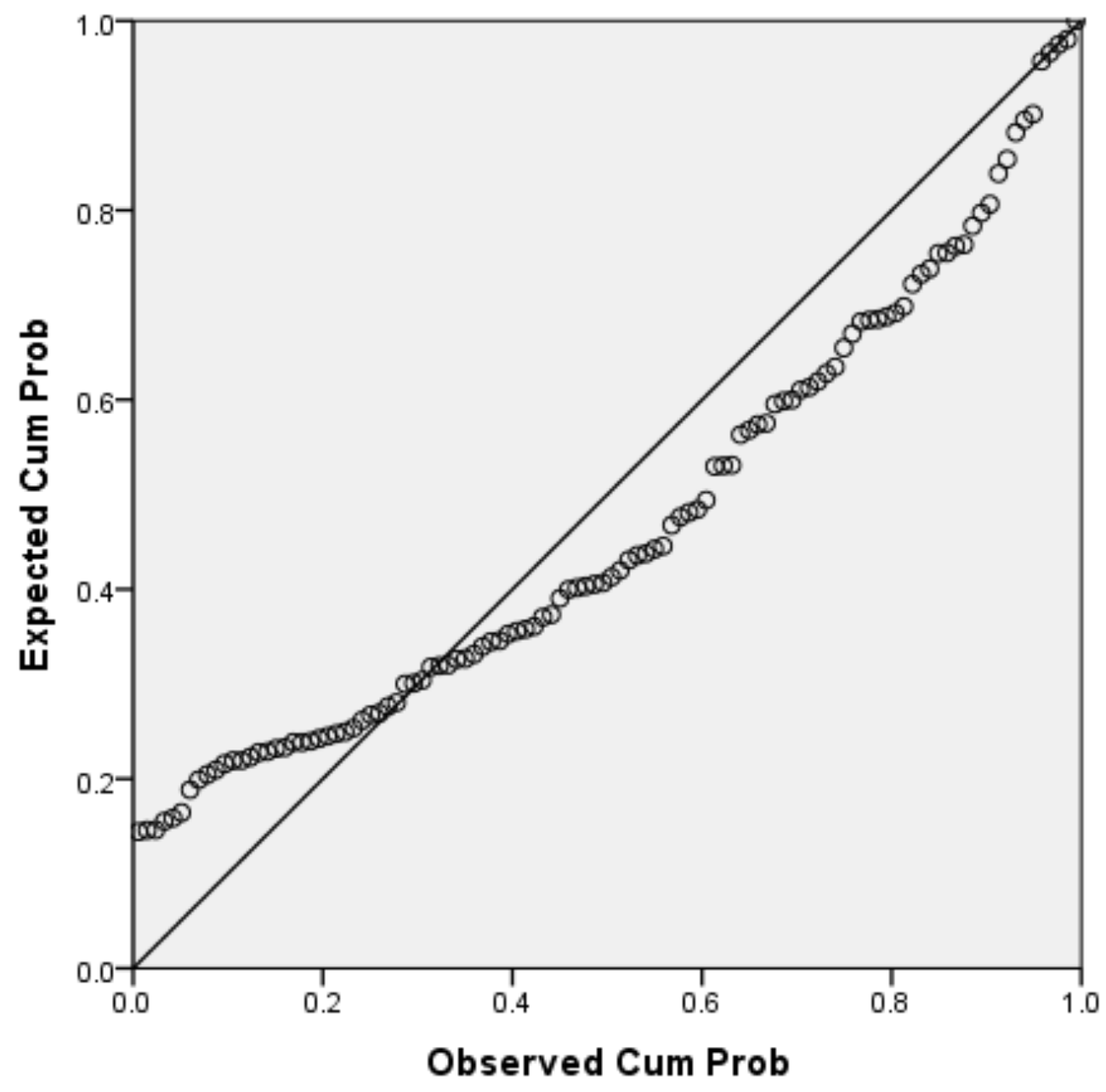

The inventory found 4,898 natural regeneration or volunteer trees and 9,204 deliberately planted trees, including 6,147 self-motivated tree plantings (showing revealed preference), and 3,063 promoted by projects, for a total of 14,108 trees. Deliberately planted trees are categorized into what we will here term "farmer preference" and "project preference". Farmers reveal their interest in planting trees and preferences for species and projected uses in the larger number of trees that they planted. "Project preference" on the other hand, is represented by the pre-selected species chosen 
by project personnel and imposed by their organization, which reveal the preferences of outside experts, which are demonstrably different than those valued by farmers.

A total of 88 species were counted on the farms. The sources of the trees overlapped with 63 species represented among the volunteers, 62 species deliberately planted and demonstrating owner preference, and five revealing project preference. Respondents listed their reasons for allowing (in the case of volunteers) or planting each species, including amenities (A) like shade and aesthetics, live fencing (LF), fruit or food for human consumption (F), wood (W) for construction and furniture, fodder (FL), traditional use like roofing material or homemade soap (T), natural medicine (M), firewood (FW), and environmental purposes (E) including habitat, food for animals, and preventing soil erosion. Rankings of the average uses/values of each species were determined across individual stated preferences of farmers, counting individual trees once for each reason they are valued, revealing some overlap to accommodate those valued for multiple reasons. Table 1 shows values cited for individual trees by origin of tree. This demonstrates that the largest variety of species (61) are preferred for amenities, followed by fruit (38) and live fences and wood (21 each), with the remaining uses represented by only a few species. Volunteers are principally maintained for their amenities $(3,354)$, followed by wood $(1,815)$ and fruit $(1,141)$, with other cited values represented by less than 1,000 individuals each. Owner preferred trees were planted primarily for live fence $(4,272)$, followed by fruit $(3,313)$ and wood $(609)$, with other reasons represented by less than 500 individuals each. Project preferred species were planted predominantly for wood $(2,556)$, followed by amenities (293) and fruit (260), with all other values represented by less than 100 individuals each. 
Of the overall 14,108 trees inventoried, most were maintained for live fencing (37.5\%), followed closely by wood (33.8\%) and then fruit (33.4\%), while only $0.005 \%$ of the total trees were valued for environmental purposes. Of the total inventoried, $96.12 \%$, or 13,561 individual trees of 64 species, were valued for two or more reasons, while only 547 individual trees of 24 species valued for a single reason. Of the total tree cover, 58 of the 88 species are native, representing 9,432 individuals, or $66.86 \%$ of the total.

Table 1. Reasons Cited for Maintaining Individual Trees by Number of Species and

\section{Origin of Trees}

\begin{tabular}{|c|c|c|c|c|c|c|c|c|c|c|}
\hline 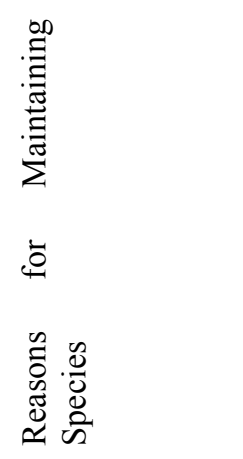 & 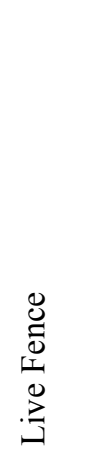 & $\begin{array}{l}7 \\
\vdots \\
3 \\
3\end{array}$ & 壱 & 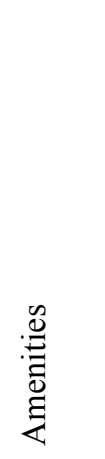 & $\begin{array}{l}\square \\
\text { o } \\
\text { 总 } \\
\text { 至 }\end{array}$ & 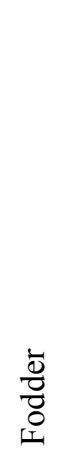 & 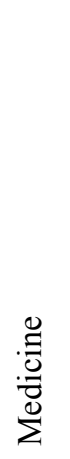 & 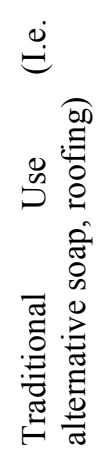 & 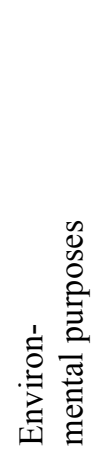 & 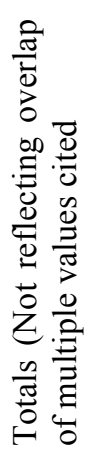 \\
\hline $\begin{array}{l}\text { Number of } \\
\text { Species Cited }\end{array}$ & 21 & 21 & 38 & 61 & 20 & 6 & 6 & 7 & 11 & 88 \\
\hline $\begin{array}{l}\text { Number } \\
\text { Volunteers }\end{array}$ & 949 & 1,815 & 1,141 & 3,354 & 624 & 778 & 255 & 211 & 78 & 4,898 \\
\hline 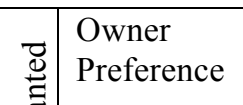 & 4,272 & 609 & 3,313 & 63 & 406 & 63 & 65 & 50 & 6 & 6,147 \\
\hline 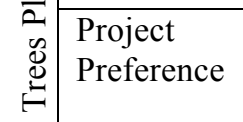 & 70 & 2,556 & 260 & 293 & 0 & 0 & 0 & 0 & 0 & 3,063 \\
\hline $\begin{array}{l}\text { Total Trees } \\
\text { Inventoried on } \\
\text { Private } \\
\text { Property }\end{array}$ & 5,291 & 4,771 & 4,714 & 3,710 & 1,030 & 841 & 320 & 261 & 84 & $\begin{array}{l}14,10 \\
8\end{array}$ \\
\hline
\end{tabular}




\section{Figure 3. Reasons Cited for Maintaining Individual Trees}

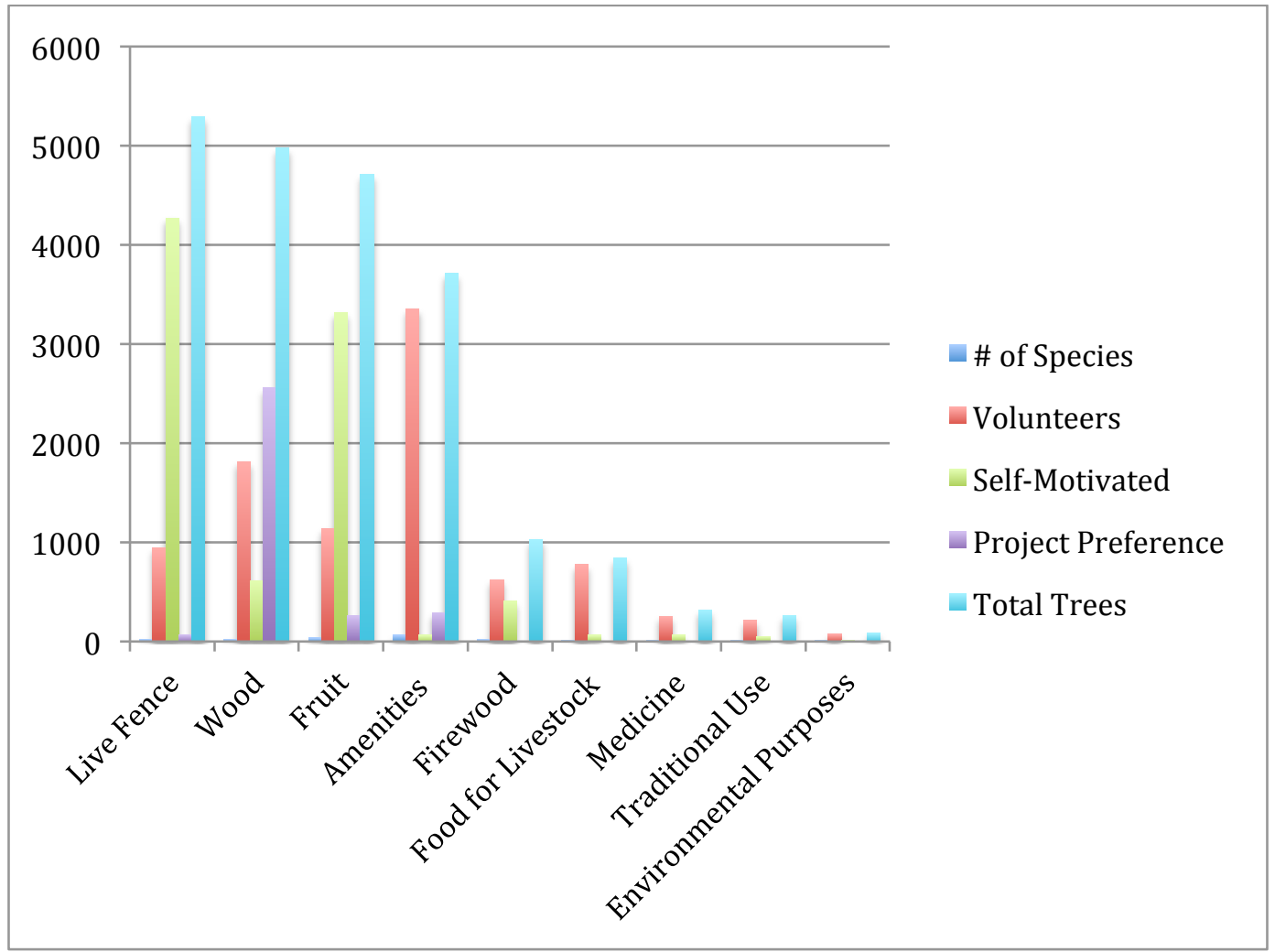

Of the trees inventoried, 24 species were represented by over 100 individuals, embodying over $89.22 \%$ of the total tree cover with 12,583 trees $\mathrm{DBH}>10 \mathrm{~cm}$. Across individual preferences of farmers, Table 2 ranks the reasons cited from most to least mentioned, demonstrating the average uses/values of each particular species. As in Table 1, individual farmers often cited several reasons for valuing their own trees, so there is some overlap. For example, of the 3,569 Cordia dentata trees, 3,502 were valued for live fencing, 406 were also valued for amenities and firewood, and 21 were valued for wood and fodder for livestock. Species were classified as introduced if new to Nicaragua since the arrival of the Europeans, or native if they always been part of the Nicaraguan landscape. Of these species, as shown in Table 2, Eucalyptus camaldulensis and Azadirachta indica are known invasive species, and six other species have been 
introduced (Kjaer and Siegismund 1996, Rojas-Sandoval and Acevedo Rodrigues 2014, Invasive Species Compendium 2014). Of these introduced species, neem and eucalyptus were imposed by project preference, resulting in these species becoming the $2^{\text {nd }}$ and $5^{\text {th }}$ most dominant species of this landscape, particularly as the natural regeneration of these species is concentrated in the areas originally planted by their respective projects. Of these most represented trees, 16 species and $66.52 \%$ of the individuals are native. While the Ministry of Forestry technical guide cites several native species such as cedro real, caoba, ceiba, and guacimo as useful for medicine or traditional uses, farmers did not include these reasons for many of the same species. The disparity may indicate a loss of traditional knowledge or a disconnect between the bureaucratic reforestation promotional practices and actual stakeholders (Maluenda et al. 2002).

Table 2. Species with Over 100 Individuals Inventoried

\begin{tabular}{|c|c|c|c|c|c|c|c|}
\hline \multirow[t]{2}{*}{$\begin{array}{l}\text { Common } \\
\text { Name }\end{array}$} & \multirow[t]{2}{*}{ Species } & \multirow[t]{2}{*}{\begin{tabular}{|l|} 
Volunteer \\
Trees
\end{tabular}} & \multicolumn{2}{|c|}{$\begin{array}{l}\text { Deliberately } \\
\text { planted }\end{array}$} & \multirow{2}{*}{\begin{tabular}{|l|} 
Total on \\
Private \\
Property
\end{tabular}} & \multirow{2}{*}{$\begin{array}{l}\text { Native }(\mathrm{N}) \\
\text { or } \\
\text { Introduced } \\
\text { (I) }\end{array}$} & \multirow{2}{*}{$\begin{array}{l}\text { Reasons } \\
\text { (Ranked from } \\
\text { most to least } \\
\text { mentioned) }\end{array}$} \\
\hline & & & $\begin{array}{l}\text { Owner } \\
\text { Preferen } \\
\text { ce }\end{array}$ & \begin{tabular}{|l|} 
Project \\
Preferenc \\
$\mathrm{e}$
\end{tabular} & & & \\
\hline Tiguilote & $\begin{array}{l}\text { Cordia dentata } \\
\text { Poir }\end{array}$ & 315 & 3254 & & 3569 & $\mathrm{~N}$ & $\begin{array}{l}\text { LF, A, FW, W, } \\
\text { FL }\end{array}$ \\
\hline Eucalypto & $\begin{array}{l}\text { Eucalyptus } \\
\text { camaldulensis }\end{array}$ & 2 & 68 & 2000 & 2070 & I & $\mathrm{W}, \mathrm{LF}, \mathrm{M}, \mathrm{A}$ \\
\hline $\begin{array}{l}\text { Madero } \\
\text { Negro }\end{array}$ & Gliricidia sepium & 438 & 0 & 523 & 961 & $\mathrm{~N}$ & $\begin{array}{l}\text { W, A, FW, LF, } \\
\text { FL, T }\end{array}$ \\
\hline Laurel & Cordia alliodora & 768 & 67 & & 835 & $\mathrm{~N}$ & $\mathrm{~W}, \mathrm{~A}, \mathrm{LF}, \mathrm{FW}$ \\
\hline Neem & Azadirachta indica & 451 & 18 & 200 & 669 & I & $\mathrm{LF}, \mathrm{A}, \mathrm{T}$ \\
\hline Mango & Mangifera indica & 225 & 292 & & 517 & I & $\begin{array}{l}\text { F, A, FL, FW, } \\
W, E\end{array}$ \\
\hline Jocote & Spondias purpurea & 19 & 441 & & 460 & $\mathrm{~N}$ & $\mathrm{~F}, \mathrm{LF}$ \\
\hline Jicaro & Crescentia alata & 434 & 19 & & 453 & $\mathrm{~N}$ & FL, F, LF \\
\hline $\begin{array}{l}\text { Guacimo de } \\
\text { ternero }\end{array}$ & \begin{tabular}{|l} 
Guazuma \\
ulmifolia
\end{tabular} & 445 & 2 & & 447 & $\mathrm{~N}$ & FL, LF, A, FW \\
\hline Naranja & Citrus sinesis & 11 & 264 & & 275 & I & $\mathrm{F}, \mathrm{M}$ \\
\hline Cacao & $\begin{array}{l}\text { Theobroma cacao } \\
\text { trinitaria }\end{array}$ & 0 & 0 & 260 & 260 & $\mathrm{~N}$ & $\mathrm{~F}, \mathrm{~A}$ \\
\hline Limon & Citrus aurantifolia & 11 & 233 & & 244 & I & $\mathrm{F}, \mathrm{M}$ \\
\hline
\end{tabular}




\begin{tabular}{|l|l|l|l|l|l|l|l|}
\hline Coco & Cocos nucifera & 0 & 235 & & 235 & $\mathrm{I}$ & $\mathrm{F}, \mathrm{M}$ \\
\hline Palmera & $\begin{array}{l}\text { Manicaria } \\
\text { saccifera }\end{array}$ & 203 & 23 & & 226 & $\mathrm{~N}$ & $\mathrm{~T}$ \\
\hline Papaya & Carika papaya & 5 & 184 & & 215 & $\mathrm{~N}$ & $\mathrm{~F}, \mathrm{M}$ \\
\hline Ceiba & Ceiba pentandra & 157 & 2 & & 159 & $\mathrm{~N}$ & $\mathrm{~W}, \mathrm{~A}, \mathrm{LF}, \mathrm{FW}$ \\
\hline $\begin{array}{l}\text { Guanacaste } \\
\text { Negro }\end{array}$ & $\begin{array}{l}\text { Enterolobum } \\
\text { cyclocarpum }\end{array}$ & 147 & 0 & & 147 & $\mathrm{~N}$ & $\mathrm{~W}, \mathrm{~A}, \mathrm{FW}, \mathrm{LF}$ \\
\hline Cedro Real & Cedrela odorata & 108 & 23 & & 131 & $\mathrm{~N}$ & $\mathrm{~W}, \mathrm{~A}, \mathrm{FW}$ \\
\hline Aguacate & Persea americana & 0 & 129 & & 129 & $\mathrm{~N}$ & $\mathrm{~F}, \mathrm{~A}, \mathrm{M}$ \\
\hline Nancite & $\begin{array}{l}\text { Byrsonima } \\
\text { crassifolia }\end{array}$ & 20 & 108 & & 128 & $\mathrm{~N}$ & $\mathrm{~F}, \mathrm{~A}$ \\
\hline Teca & Tectona grandis & 0 & 120 & & 120 & $\mathrm{I}$ & $\mathrm{W}$ \\
\hline Guayaba & Psidium guajava & 83 & 31 & & 114 & $\mathrm{~N}$ & $\mathrm{~F}, \mathrm{FW}, \mathrm{A}, \mathrm{LF}$ \\
\hline Michiguiste & $\begin{array}{l}\text { Pithecellobium } \\
\text { dulce }\end{array}$ & 114 & 0 & & 114 & $\mathrm{~N}$ & $\mathrm{~W}, \mathrm{~A}, \mathrm{FW}$ \\
\hline Mamoncillo & $\begin{array}{l}\text { Melicoccus } \\
\text { bijugatus }\end{array}$ & 69 & 36 & & 105 & $\mathrm{I}$ & $\mathrm{F}, \mathrm{A}$ \\
\hline
\end{tabular}

While the vast majority of the trees surveyed demonstrate farmer preference, the inventory was also used to evaluate survivorship of the project preference trees reportedly planted by the MCC and INTA projects outlined in Chapter 2. These findings are summarized in Table 3, which demonstrates that while past projects report high success rates, there seems to be little follow-up to ensure long-term survival and adoption of best practices in tree management. As Table 3 shows, the inventory revealed that only 260 of the 6,000 cocoa saplings reported planted by the MCC in 2007 year survived to be counted in 2015. Similarly low success is evident in the madroño project. Although the extension technician noted 1,000 trees transplanted, INTA conducted no home visits to verify. For their part, participants recall the difficulties of handling the small, dust-like seeds and poor germination rates, factors that may help explain the existence of only 80 individuals when this inventory was conducted.

The extension office of INTA's neem, an alien species originally planted along a public path as live fencing, now monopolizes the undergrowth with its own seedlings, 
and the original 200 saplings have ballooned to 669. Eucalyptus, INTA's other alien species introduction, also seems to be thriving, as 2000 were planted and 2070 were found in the inventory, possibly a great success on survival rate but with environmental consequences that remain to be seen. However, the plantings of Gliricidia sepium, a nitrogen-fixing native species valued for multiple reasons that also provides important habitat, may demonstrate a positive convergence of farmer and project preference, as 961 trees were surveyed, nearly double the number planted by the project. (Griscom and Ashton 2011). Technical training was provided in three cases but not the others, and did not seem to be a good indicator of tree survival.

Table 3. Tree Planting Projects in the Three Communities Since 1990

\begin{tabular}{|c|c|c|c|c|c|c|c|}
\hline 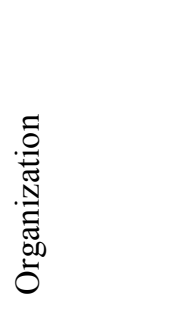 & 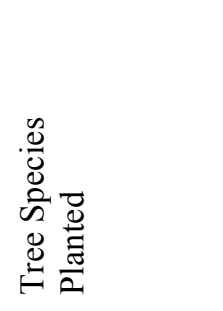 & 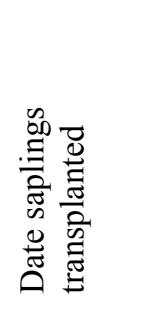 & 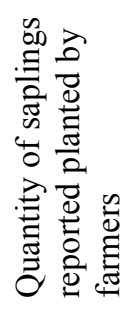 & 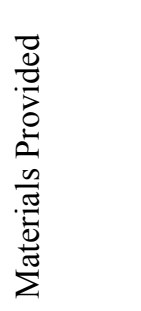 & 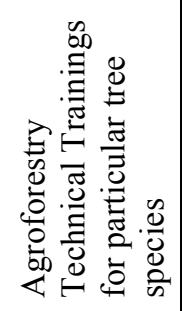 & 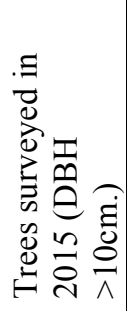 & 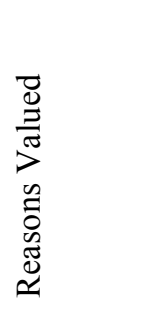 \\
\hline $\begin{array}{l}\text { Millennium } \\
\text { Challenge } \\
\text { Corporation }\end{array}$ & $\begin{array}{l}\text { Theobroma } \\
\text { cacao } \\
\text { trinitaria } \\
\text { (Cocoa) }\end{array}$ & $\begin{array}{l}\text { November } \\
2007\end{array}$ & 6,000 & Saplings & 1 & 260 & $\mathrm{~F}, \mathrm{~A}$ \\
\hline \multirow{4}{*}{$\begin{array}{l}\text { National } \\
\text { Institute of } \\
\text { Agricultural } \\
\text { Technology } \\
\text { (INTA) }\end{array}$} & $\begin{array}{l}\text { Eucalyptus } \\
\text { camaldulensis } \\
\text { (Eucalyptus) }\end{array}$ & 2000 & 2,000 & $\begin{array}{l}\text { Seeds, } \\
\text { nursery } \\
\text { bags }\end{array}$ & 1 & 2070 & $\begin{array}{l}\text { W, LF, M, } \\
\text { A }\end{array}$ \\
\hline & $\begin{array}{l}\text { Gliricidia } \\
\text { sepium } \\
\text { (Madero } \\
\text { Negro) }\end{array}$ & 2001 & 523 & $\begin{array}{l}\text { Seeds, } \\
\text { nursery } \\
\text { bags }\end{array}$ & 0 & 961 & $\begin{array}{l}\text { W, A, } \\
\text { FW, LF, } \\
\text { FLT }\end{array}$ \\
\hline & $\begin{array}{l}\text { Azadirachta } \\
\text { indica (Neem) }\end{array}$ & 2002 & 200 & Seeds & 1 & 669 & $\mathrm{LF}, \mathrm{PA}, \mathrm{T}$ \\
\hline & $\begin{array}{l}\text { Calycophyllum } \\
\text { candidissimum } \\
\text { (Madroño) }\end{array}$ & 2005 & 1,000 & Seeds & 0 & 80 & PA, W \\
\hline
\end{tabular}

The Peace Corps from 2013-2015 conducted an additional tree-planting project. Participants attended three training sessions with the Ministry of Forestry each year, paid 
$50 \%$ of the costs of materials (including seeds and nursery bags), and received three home visits, including one to verify that the trees had been transplanted. As participants were able to select the species they wanted to plant, limited only by seed availability, this project attempted to follow stakeholder preferences, rather than impose project preference applied by previous projects. With the exception of 32 Moringa oleifera and 57 Carica papaya trees, the inventory was not able to include the majority of the trees planted in coordination with the Peace Corps, since most were still below $10 \mathrm{~cm} \mathrm{DBH}$. Quantity and species selections as well as germination rates are included in Table 4. As demonstrated in the table, farmers selected eleven native species, representing $80.84 \%$ of the total trees planted in this project. In addition, wood is the first ranked reason $69.32 \%$ of the total trees were planted and all but one of the species were selected repeatedly for nursery plantings, indicative of preference and possibly positive planting experience in previous years.

The germination rates shown in Table 4 appear to be within the range of other trials of these species, for example: Bombascopsis quinata typically has a germination rate of $77 \%$, Gliricidia sepium usually demonstrates around $90 \%$ germination, and Enterolobium cyclocarpum usually has a germination rate of $40-53 \%$ (Simons and Stewart 1994, Chacko and Chandrasekhara 1997, Orwa et al. 2009). These findings demonstrate that seeds sown by farmers in field conditions can replicate germination rates of seeds sown in laboratory conditions. 
Table 4. Peace Corps Tree Planting Project 2013-2015

\begin{tabular}{|c|c|c|c|c|c|}
\hline Organization & $\begin{array}{l}\text { Tree Species } \\
\text { Planted }\end{array}$ & $\begin{array}{l}\text { Date saplings } \\
\text { transplanted }\end{array}$ & $\begin{array}{l}\text { Quantity of } \\
\text { saplings } \\
\text { reported planted } \\
\text { by organization }\end{array}$ & $\begin{array}{l}\text { Germination } \\
\text { Rates }\end{array}$ & $\begin{array}{l}\text { Reasons } \\
\text { Valued }\end{array}$ \\
\hline \multirow[t]{12}{*}{ Peace Corps } & $\begin{array}{l}\text { Swintenia } \\
\text { humilis Zucc. } \\
\text { (Mahogany) }\end{array}$ & $\begin{array}{l}\text { May 2014, } \\
\text { June 2015 }\end{array}$ & 240 & $84.1 \%$ & $\mathrm{~W}, \mathrm{~A}$ \\
\hline & $\begin{array}{l}\text { Cedrela } \\
\text { odorata L. } \\
\text { (Cedar) }\end{array}$ & $\begin{array}{l}\text { May 2014, } \\
\text { June 2015 }\end{array}$ & 210 & $44.5 \%$ & $\begin{array}{l}\text { W, A, } \\
\text { FW, LF }\end{array}$ \\
\hline & $\begin{array}{l}\text { Guazuma } \\
\text { ulmifolia Lam. } \\
\text { (Guacimo) }\end{array}$ & $\begin{array}{l}\text { June } 2013 \text {, } \\
\text { May } 2014\end{array}$ & 314 & $74.3 \%$ & $\begin{array}{l}\text { FL, LF, } \\
\text { A, FW }\end{array}$ \\
\hline & $\begin{array}{l}\text { Bombacopsis } \\
\text { quinatum } \\
\text { (Pochote) }\end{array}$ & $\begin{array}{l}\text { June } 2013, \\
\text { May 2014, } \\
\text { May 2015 }\end{array}$ & 436 & $71.6 \%$ & $\begin{array}{l}\text { W, A, } \\
\text { FW }\end{array}$ \\
\hline & $\begin{array}{l}\text { Enterolobium } \\
\text { cyclocarpum } \\
\text { (Guanacaste } \\
\text { Negro) }\end{array}$ & $\begin{array}{l}\text { May 2014, } \\
\text { May 2015 }\end{array}$ & 267 & $\begin{array}{l}52.7 \% \text { (when } \\
\text { placed in } \\
\text { boiled water } \\
\text { for } 24 \text { hours) }\end{array}$ & $\begin{array}{l}\text { W, A, } \\
\text { FW, LF }\end{array}$ \\
\hline & $\begin{array}{l}\text { Cordia } \\
\text { allodora } \\
\text { (Laurel or } \\
\text { Bay) }\end{array}$ & $\begin{array}{l}\text { June } 2013 \text {, } \\
\text { May } 2015\end{array}$ & 184 & $\begin{array}{l}23.1-32.4 \\
\text { (some insect } \\
\text { damage) }\end{array}$ & $\begin{array}{l}\text { W, A, } \\
\text { LF, FW }\end{array}$ \\
\hline & $\begin{array}{l}\text { Glirincidia } \\
\text { sepium } \\
\text { (Madero } \\
\text { Negro) }\end{array}$ & $\begin{array}{l}\text { May 2014, } \\
\text { May 2015 }\end{array}$ & 1,500 & $84.6 \%$ & $\begin{array}{l}\text { W, A, } \\
\text { FW, LF, } \\
\text { FL, T }\end{array}$ \\
\hline & $\begin{array}{l}\text { Calycophyllum } \\
\text { candidissiumD } \\
C \\
\text { (Madroño) }\end{array}$ & June 2013 & 47 & $45.2 \%$ & $\mathrm{~A}, \mathrm{~W}$ \\
\hline & $\begin{array}{l}\text { Moringa } \\
\text { oleifara } \\
\text { (Marango) } \\
\end{array}$ & $\begin{array}{l}\text { April 2014, } \\
\text { May } 2015\end{array}$ & 858 & $93.7 \%$ & $\mathrm{M}, \mathrm{FL}, \mathrm{A}$ \\
\hline & $\begin{array}{l}\text { Tebebuia } \\
\text { rosea (Roble) }\end{array}$ & $\begin{array}{l}\text { May 2014, } \\
\text { May 2015 }\end{array}$ & 132 & $78 \%$ & $\begin{array}{l}\text { W, A, } \\
\text { FW, LF }\end{array}$ \\
\hline & $\begin{array}{l}\text { Ceiba } \\
\text { Pentandra } \\
\text { (Ceiba) }\end{array}$ & $\begin{array}{l}\text { May 2014, } \\
\text { May 2015 }\end{array}$ & 136 & $\begin{array}{l}75.1 \% \text { (when } \\
\text { placed in } \\
\text { water for } 3 \\
\text { days) } \\
\end{array}$ & $\begin{array}{l}\text { W, A, } \\
\text { LF, FW }\end{array}$ \\
\hline & $\begin{array}{l}\text { Carica papaya } \\
\text { (Papaya) }\end{array}$ & $\begin{array}{l}\text { April 2013, } \\
\text { May } 2015\end{array}$ & 155 & $\mathrm{~N} / \mathrm{A}$ & $\bar{F}, \mathrm{M}$ \\
\hline
\end{tabular}

While the projects mentioned above are highlighted to increase information available to future reforestation projects, variables influencing farmers' decisions to participate in these projects are outlined in Table 5. Almost all households (94.5\%) 
planted some trees on their own, showing high motivation for planting trees. A smaller but still robust $75 \%$ participated in one or more of the aforementioned agroforestry projects, while 11 households $(25 \%)$ did not participate. The descriptive statistics are consistent with findings in the literature, demonstrating that participation was more likely to increase with education, household size, social capital, water availability, and on-farm work. Women seem more likely to participate than men, probably because of their availability to participate in meetings, and to gender specific recruitment by some groups (i.e., PLANicaragua, INTA). Dry season water availability can be a limiting factor for some households, as nurseries must be established in the dry season and hauling water from adjacent properties increases opportunity costs in time and resources spent. For this same reason, household size may be a correlated influencing factor on participation, as large families may have increased labor availability. As households who work off-farm have rigid schedules, they are often unable to participate in projects, particularly as projects tend to have several training sessions, frequently during the weekday. This difficulty is corroborated by the survey, as meeting time was second only to corruption as the most cited problem with project participation (most of the corruption complaints stem from a failed seed bank project by PLANicaragua, not specifically from a tree planting project).

Participants seem to be slightly younger and have slightly higher education levels, but as 4.6 years is the participants' average completed years of education (reflective of the national average of 4.5), these numbers are not strikingly different (International Development Association 2007). There is a marked decrease in participation as property size and cultivated land increase, corroborating the tree density findings already 
mentioned. This decrease may also indicate that the crops sown in this region, particularly sugarcane and peanuts, are not conducive towards tree planting, as they use highly mechanized cultivation methods and sugarcane is burnt annually. However, participation seems to increase with land dedicated to pasture, indicating that this landuse practice is more conducive towards agroforestry and reforestation projects. The agricultural group participation, aside from being an indicator of social capital, is also affected by information channels, as these groups are often the ones to sponsor projects, and new project sponsors often get a list of possible participants from previous groups and projects. These practices may indicate that while information flows within the groups, keeping participants apprised of new projects, the larger community may be left out.

Table 5. Factors Influencing Participation in the Tree Planting Projects

\begin{tabular}{|l|l|l|l|l|}
\hline & \multicolumn{3}{|l|}{ Non-Participants } & \multicolumn{2}{l|}{ Participants } \\
\hline & Mean & SD & Mean & SD \\
\hline $\begin{array}{l}\text { Gender (0=Male, } \\
\text { 1=Female) }\end{array}$ & 0.167 & 0.389 & 0.625 & 0.492 \\
\hline Age & 54.917 & 11.285 & 51.719 & 11.663 \\
\hline Education Level & 3.583333 & 3.848455 & 5.09375 & 3.041216 \\
\hline Household Size & 3.166667 & 1.642245 & 4.875 & 2.511265 \\
\hline Works Off-Farm & 0.75 & 0.452267 & 0.375 & 0.491869 \\
\hline $\begin{array}{l}\text { Participated in X \# of } \\
\text { Agricultural Groups }\end{array}$ & 0.5 & 0.522233 & 1.21875 & 1.099395 \\
\hline $\begin{array}{l}\text { On-Farm Dry Season } \\
\begin{array}{l}\text { Water Availability } \\
\text { (0=No, 1=Yes) }\end{array}\end{array}$ & 0.166667 & 0.389249 & 0.40625 & 0.498991 \\
\hline Property Size & 4.106373 & 5.449275 & 3.276185 & 5.099118 \\
\hline Crops Ha & 2.698667 & 3.47275 & 0.672375 & 1.396967 \\
\hline Head of Cattle & 8.916667 & 21.00848 & 8.78125 & 17.04025 \\
\hline Pasture Ha & 1.76 & 4.375934 & 2.233 & 4.056615 \\
\hline
\end{tabular}


A binary logistic regression analysis (Figure 3), was conducted to evaluate the significance of these findings. The analysis measured the strength of the response of the dependent variable of project participation for the independent variables where $\alpha=0.05$. This indicated that factors positively correlated to participation include only agricultural group participation and land dedicated to pasture. Significant factors negatively correlated to participation include only hectares planted and property size. The negative correlation between participation and property size and cropland corroborates findings of tree density, as tree density decreased as property size and cropland increased.

\section{Figure 4. Participation Binary Logistic Regression}

\begin{tabular}{|ll|l|l|l|l|l|l|}
\hline & B & S.E. & Wald & df & Sig. & Exp(B) \\
\hline Step $1^{\mathrm{a}}{ }^{\mathrm{n}}$ & Education Level & .356 & .225 & 2.497 & 1 & .114 & 1.427 \\
& Household Size & 1.175 & .715 & 2.703 & 1 & .100 & 3.240 \\
& & & & & & \\
Agroforestry & 3.397 & 1.676 & 4.110 & 1 & .043 & 29.881 \\
Group & & & & & & \\
Participation & 3.406 & 2.087 & 2.662 & 1 & .103 & 30.131 \\
Gender & -3.242 & 1.638 & 3.919 & 1 & .048 & .039 \\
Hectares Planted & -2.090 & 1.017 & 4.227 & 1 & .040 & .124 \\
Pasture Land & 1.934 & .971 & 3.971 & 1 & .046 & 6.919 \\
Property Size & -7.429 & 4.238 & 3.073 & 1 & .080 & .001 \\
Constant &
\end{tabular}

a. Variable(s) entered on step 1: Education Level, Household Size, Agroforestry Group Participation, Gender, Hectares Planted, Pasture Land, Property Size, Age, Off-Farm Work, Water Availability, Head of Cattle.

The data show that farmers incurred costs in transportation, materials and labor to plant trees, suggesting a minimum value, revealed preference and a basic willingness to pay. Participants traveled an average $12.9 \mathrm{~km}$ to retrieve seeds, and worked from .5-12 days establishing their nurseries and transplanting the trees. Maintenance was estimated at 30 minutes per day, but varied widely depending on water source and size of nursery 
and so is not included in these calculations. Nine participants used hired labor and spent an average total cost of $\$ 0.75$ per tree from seed to transplanting sapling. For the 77 purchased trees, participants spent an average $\$ 1.37$ per tree, and the most reported reason for purchasing was timber, followed by fruit, though limited by nursery availability. Over $34 \%$ of participating households used hired labor for an average 84 cordobas per day, or $\$ 3.11$ for a mean 37.4 weeks per year. These expenditures demonstrate that some households have sufficient capital to afford an extra pair of hands, but wages also reflect the extreme poverty of the region. These expenses represent part of the participants' investment, costs which must be outweighed by benefits (perceived or otherwise) in order for the rational farmer to justify tree planting (Foundjem-Tita et al. 2013). While these factors may have influenced participation in tree planting projects, the survey also revealed some of participants' specific preferences in planting trees.

Moving to the riparian forest component of the landscape, the five sample plot demonstrated an average density of 660 stems $>10 \mathrm{~cm}$. per ha with a total of 21 different species. The law explicitly prohibits and logging, removal of vegetation or disturbance within 50 meters on either side of the river, but there was evidence of all of these activities, including sugarcane planted within 20 meters of the river (Law 462). There was a surprising lack of invasive species usually expected in secondary forest, but this may be a result of the small sample size. While the riparian area is a crucial corridor within this landscape matrix, secondary forest recovery may be impeded by consistent extraction by households for fuel wood and timber. Twenty household participants reported collecting fuel wood from the riparian areas, and were asked to estimate how many $16 \times 2 \times 2$ " pieces of fuel wood they used each week. Although weight is usually used 
to measure fuel wood consumption, a scale was not available and this is only used to demonstrate an estimate. From this, an estimated 129,280 in. ${ }^{3}$ are extracted weekly from the community's riparian area, adding to over 184,320 in. $^{3}$ used overall by participants from various sources.

The four loggers were asked in informal interviews to list their last 10 logging jobs within these three villages, extending from May to August, 2015, demonstrated in the table below. Although most of their work is illegal, these men, between the ages of 27 and 51, are frequently hired and generally accepted by the community. All report having at least one incident with authorities, with consequences ranging from confiscation of their chainsaw to time in jail. One recounted a recent foray with the law in which he was caught with an espevel (Anacardium excelsum) from the riparian area, lost his tractor and chainsaw, spent six days in prison, regained his tractor, and signed a contract to plant 10,000 saplings. This final objective was only hazily recalled and 5 months later he still hadn't received any follow-up. The four men, who range from illiterate to some primary education, all admit to some instability in their work, but calculate an income of up to 8,000 cordobas $(\sim \$ 296)$ per month. Despite instability, this income is above the Nicaraguan average annual income of $\$ 1,870$ (World Bank Development Indicators 2014). 
Table 6. Number of Trees Reported Cut by Loggers within the Three Communities, May to August 2015.

\begin{tabular}{|c|c|c|c|c|c|c|c|c|c|c|c|c|}
\hline \multicolumn{2}{|c|}{$\begin{array}{l}\text { Common } \\
\text { Name }\end{array}$} & $\begin{array}{l}\pi \\
0 \\
0 \\
\tilde{0}\end{array}$ & 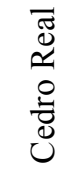 & $\frac{\pi}{\pi}$ & 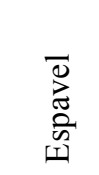 & 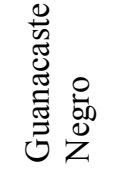 & 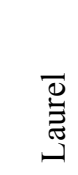 & 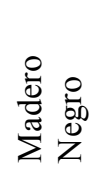 & 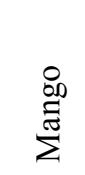 & $\begin{array}{l}0 \\
0 \\
\frac{0}{0} \\
0 \\
0\end{array}$ & $\begin{array}{l}0 \\
\frac{\pi}{0} \\
\frac{\pi}{0} \\
0 \\
0 \\
0\end{array}$ & 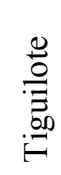 \\
\hline \multicolumn{2}{|c|}{ Species } & 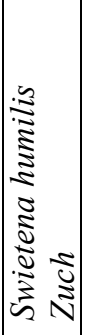 & $\begin{array}{l}0 \\
0 \\
0 \\
0 \\
0 \\
0 \\
0 \\
0 \\
0 \\
0 \\
0 \\
0 \\
0\end{array}$ & 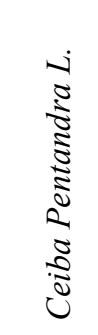 & 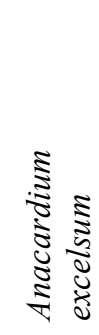 & 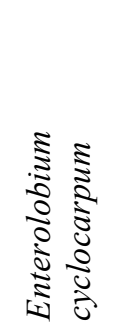 & $\begin{array}{l}0 \\
0 \\
0 \\
0 \\
0 \\
0 \\
0 \\
0 \\
0 \\
0\end{array}$ & 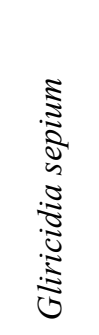 & 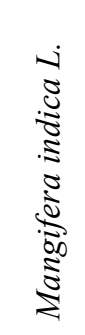 & 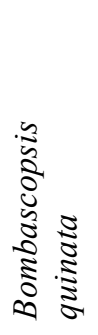 & 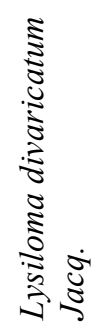 & $\begin{array}{c}0 \\
0 \\
0 \\
0 \\
0 \\
0 \\
0 \\
0\end{array}$ \\
\hline \multirow[b]{2}{*}{ 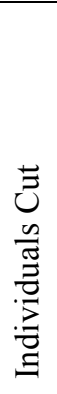 } & 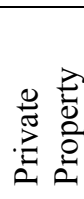 & 0 & 1 & 4 & 0 & 3 & 19 & 4 & 1 & 2 & 4 & 3 \\
\hline & 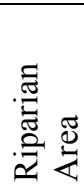 & 1 & 2 & 2 & 11 & 0 & 6 & 0 & 0 & 1 & 10 & 0 \\
\hline \multicolumn{2}{|c|}{$\begin{array}{l}\text { Average } \\
\text { DBH } \\
\text { when cut }\end{array}$} & 75 & 63.3 & 126.6 & 123.6 & 166.6 & 42 & 48.7 & 90 & 70 & 139.2 & $\begin{array}{l}56 . \\
6\end{array}$ \\
\hline \multicolumn{2}{|c|}{$\begin{array}{l}\text { Reasons } \\
\text { Cut }\end{array}$} & W & W & W & W & W & W & W & $\begin{array}{l}\text { W, } \\
\text { FW, } \\
\text { D }\end{array}$ & W & W & $\begin{array}{l}\text { D, } \\
\text { W, } \\
\text { FW }\end{array}$ \\
\hline
\end{tabular}

As Table 6 demonstrates, the loggers reported cutting 74 trees from May $1^{\text {st }}, 2015$ to August $1^{\text {st }} 2015$, (excluding 2,652 Eucalyptus trees removed from the plantation within this time period) from the entire landscape. Of the trees removed within just this 3 month period, 33 were from the riparian forest, demonstrating an important dynamic between elements in the landscape matrix. Only 11 species are included, all natives, with three species making up $67.56 \%$ of trees cut: Cordia alliodora, Lysiloma divercatum Jacq, and Anacardium excelsum. Although the inventory found that Cordia alliodora is the fourth 
most common tree on private property, only 56 individuals of Lysiloma divercatum were found, and not one living specimen of Anacardium excelsium was included in either the private property inventory or the riparian area samples. As these species demonstrate sufficient value to merit paying the loggers' fees as well as running the risk of being reported (admittedly small but still mentioned by some), they should be considered for future tree planting projects. They earned $\$ 11-60$ per tree, which they explained they calculate depending on size, complication of cut, proximity and risk (both physical and legal). Because of their varying prices, the highest earning species cannot be calculated from these interviews, but the fact that these three communities can support at least four loggers highlights a demand for trees, and their wages far exceed those earned by the hired hands. Of all the trees reportedly eliminated, only 32 of the Eucalyptus trees received the mandatory permission from INAFOR, representing less than $2 \%$ of the total trees cut.

The samples evaluated in the Eucalyptus plantation revealed an average density of 3,900 individuals with $\mathrm{DBH}>10 \mathrm{~cm}$. per hectare, for a total 234,000 over the 60 ha. The density is more than double the recommended stocking density for other Eucalyptus species of 1,667 individuals per hectare, but the owner's ailing health has prevented him from taking more active management, and he has been considering selling (Galloway et al. 2001, Alcom et al. 2007). Although the plantation owner is arguably the wealthiest community member, his prosperity stems from several practices, including sugarcane, and dairy and beef cattle, from which he claims to earn the most stable part of his income, rather than the plantation. A revenue per hectare calculation could not be conducted, due to inconsistencies in record keeping and eucalyptus prices. However, the 
plantation reported cutting 2,652 Eucalyptus trees from May $1^{\text {st }}$ to August $1^{\text {st }}, 2015$, an amount the owner considered average. Less than 30 of these trees were sold to Tom Valle community members, while the rest were sold mostly to wealthier buyers in the city or along the coast, where an increasing population of Americans, Canadians and Europeans favor the costlier Eucalyptus for open-aired ranch construction. While plantations of other Eucalyptus species have successfully supported natural regeneration of native species, the samples found in the Tom Valle plantation only found one individual cortez tree $\mathrm{DBH}>10 \mathrm{~cm}$, perhaps due in part to the dense overcrowding of trees.

\section{Discussion}

In a typical Central American agricultural matrix, trees were mostly found as live fences, dispersed trees in pasture, and denser plantings of fruit trees in patios, woven with denser corridors of riparian forest, showing some recovery of TDF species despite the dominance of agriculture (Barance et al 2003, Harvey et al 2005, Harvey et al 2011, Griscom and Ashton 2011). However, the majority of this recovery seems to be a result of deliberate plantings by farmers, something perhaps not previously well-documented, as previous studies emphasize natural regeneration, project plantings, and protecting practices (Barrance et al 2003, Garen et al 2009, Hall et al 2011) and few acknowledge the actual planting practices by the farmers themselves (Garen et al 2011). While natural regeneration in other regions often makes up over $85 \%$ of inventoried trees, here they only represent $34.72 \%$, demonstrating perhaps a lower regeneration rate due to its historical clear-cutting as well as the effects of a clear motivation to plant trees (de Sousa et al 2016). Sugarcane production, in comparison with other crops, may also suppress natural regeneration. The overall tree density found on farms can be used as a reference 
for future studies, particularly in agricultural matrices of the tropical dry forest region, creating a baseline for this area as well as adding to the literature that examines tree density within separate components of farms such as windbreaks (Harvey 2000), riparian forests (Griscom et al 2011), and dispersed trees in pasture (Hervey and Haber 1999, Harvey et al 2011).

Species diversity of these trees on farms is comparable to those found within other agricultural matrices of the region, within the range of 27-99 species (Harvey et al 2005, Garen et al 2011). As found in other tropical dry forest mosaics of Central America, landholders valued a wide diversity of species for multiple uses, and tree management decisions include selectively tolerating natural regeneration, actively planting, and logging trees dependent on their different values (Aguilar and Condit 2001, Barrance et al. 2003, Love and Spaner 2005, Garen et al. 2011). Both revealed and stated preferences for species in this study differ from other areas, with far fewer valued for medicinal uses and more valued for physical attributes, validating the idea that land restoration and planting projects should be site specific (Garen et al 2011). Although plot size was not influential to tree adoption in other regions, this study revealed it to be an important factor in both on-farm tree density and tree planting project participation (Garen et al 2009).

While tree density and species diversity are comparable to other agricultural matrices, a few species dominate the landscape, as the top ten account for over $72 \%$ of the tree cover. While some species are found throughout the regional landscapes, differences in dominating species emphasize the importance of site specificity (Harvey et al 2005, Griscom et al 2011). Because of this monopolization, and as repeated burning, 
over-grazing, exotic grasses, intensely mechanized cultivation methods, and sparse populations of parent tree seed sources have probably resulted in a loss of soil productivity, the region is an excellent candidate for enrichment plantings of native species (Griscom and Ashton 2011). Nicaragua increased it's sugarcane planted area in 2013 by $13 \%$ to 67,128 ha, a number expected to surge another $20 \%$ by 2016 , while peanut plantations occupy 42,253 ha, $82 \%$ of which is concentrated in the west, directly affecting the study site (USDA 2013). These production increases demonstrate a dynamic that will negatively transform the landscape mosaic in these communities, as the highly mechanized cultivation of these crops compacts soil, and reduces soil fertility and productivity, adding urgency to increasing tree cover in the other elements of the landscape (Naranjo de la F. et al. 2006, de Oliveira Cardoso et al 2012). While the forested riparian corridors that exist within this landscape provide a great resource for passive restoration, hosting a density and species diversity comparable to other disturbed dry forests and facilitating relatively diverse second growth forests, the diversity of species composition of pasture trees and live fences can be promoted to encourage further diversity restoration (Valencia 1998, Sagar and Singh 2006, Griscom and Ashton 2011). If tree density on farms can be increased, as farmers clearly have an interest in promoting, natural regeneration of some species may be increased with improved genetic variation, pollen flow and seed dispersal, improving biodiversity while increasing habitat provision, ecosystem services, and adding value for landholders (Fuchs et al. 2003, Barrance 2003, Wishnie 2007, Hall 2010, Haglund et al 2011, Tschamtke et al 2012, Mendoza et al 2014, Benegas et al 2014). 
However, creating habitat for biodiversity should not be considered the primary objective in tree planting projects, as environmental services and habitat are not representative of either stated or revealed stakeholder preferences (Garen et al 2011). Live fencing is valued and can be a means of establishing more trees within the agricultural mosaic (Love et al 2009, Harvey et al 2011). Although not ranked as important as other reasons, planting species that are also suitable for firewood close to the house may be seen as beneficial to the family as well as to vulnerable riparian areas, as the average Nicaraguan family spends an estimated 47 minutes per day gathering firewood (United Nations, 2010). Additionally, the clearly expressed value for trees for their physical attributes such as shade provides a great opportunity in sweltering Chinandega for a creative campaign, juxtaposing a bare, simmering camino with a treeshaded patio, hammock swaying seductively beneath the leaves. Live fences, already a revealed preference by farmers in the region, should continue to be promoted, providing great potential in sustainable land management (Harvey et al. 2005).

From those projects in which preference was imposed, a few regionally-specific lessons can be learned. The MCC cocoa project reportedly distributed the trees to be planted in November, the very beginning of the long, thirsty dry season, and as 8 of the 9 project-participating farmers did not have access to irrigation (the main reason cited for not establishing a tree nursery), many of the saplings died. When asked if they'd plant cocoa again, most participants preferred a hardwood species for personal or commercial extraction, but said they'd accepted the cocoa because it was what was offered, demonstrating imposed project preference. The project may have had higher success in other areas, but this unacceptably low survival rate demonstrates the necessity of having a 
better understanding of environmental constraints, local resources and availability of water, seasonal calendars and farmer preferences to improve lasting reforestation efforts.

Community members should be included in the species selection process and project planning, as they have knowledge of the local demand, market possibilities, resource availability, planting techniques and their own preferences that are informed by both conscious and unconscious factors that cannot be replicated by a cursory outside glimpse (Current and Scherr 1995, Garen et al 2011). Several native species represent a convergence of stated and revealed preferences and provision of social, economic and environmental benefits, as they are prized locally for multiple uses, have marketable value, demonstrate acceptable germination rates in practice, and can increase connectivity for many species as live fences or dispersed pasture trees. Species suggested by the literature review and verified as valuable by this study include Enterolobium cyclocarpum, Anacardium excelsum, Ceiba pentandra, Tabebuia rosea, Cedrela odorata, Gliricidia sepium, Guazuma ulmifolia, Swietenia humilis, and Bombascopsis quinata (Griscom et al 2005, Love and Spaner 2005, Galicia 2008, Hall et al 2010, Garen et al 2011). Both the literature review and stakeholders likewise suggested Tabebuia chrysantha, Anacardium excelsum and Lysiloma divericatum, but a reliable seed source was not available and should be developed (Williams-Linera and Lorea 2009).

While fast-growing exotic timber species like eucalyptus and teak have been promoted throughout the region, they are more expensive to establish than other agroforestry opportunities, inhibit diversity and ignore stakeholder preferences for diverse, native, multi-purpose species (Aguilar and Condit 2001, Barrance et al. 2003, Wishnie et al. 2007, Love et al. 2009). Although planted primarily for timber production, 
these plantations were expected to provide secondary benefits such as habitat provision, fire reduction, and improved soil structure. Both Eucalyptus camaldulensis, a known aggressive invader and a high water consumption species, and Tectona grandis demonstrate factors detrimental to native recruitment, altering soil chemistry, casting dense shade, and shedding fire-prone leaves (Healey and Gara 2003, Boley et al. 2009, Dzikiti et al. 2016). While increased risk of fire and lower water tables in an already dry region demonstrate obvious reasons these species should be avoided, their supposed primary objective as an economic driver through timber provision must also be questioned by this study, as neither species seems to serve the local market. The owner of the teak explained that the nearby communities could not afford this species, nor could he afford the bureaucratic process and bribes he would need to export, so teak is not only limited in providing ecosystem services, the economic benefits are also currently out of reach, necessitating further extension activities for these exotic species (Current and Scherr 1995). In addition, exotic species like Eucalyptus and neem often gain international attention, leading to big investments and promotional campaigns, but the enthusiasm often lacks long-term research and insight into possible risks of species introduction, including environmental and socio-economic impacts (Achten et al. 2014). While these lessons have been repeated with Jatropha carcus and Artemesia annua, they have remained unheeded as new species like Allanblackia, Argania spinosa, and Moringa oleifera continue to be proclaimed "miracle trees" (Achten et al. 2014). The Eucalyptus market, albeit external/remote, and the native species cut, highlight local demand for timber. 
This demand can be met by planting diversified native timber plantations or smallholder systems, improving ecosystem services like habitat provision while supplying social and economic benefits. Although a long-term investment, timber planted for the ready market in their own communities can be cultivated with fewer inputs than traditional crops, reducing financial and environmental costs and often yielding higher income, while providing a safety net in crisis years of drought, pests, or market failures (de Sousa et al 2016). As 59.3\% of households in Nicaragua derive income from agriculture, with over $40 \%$ living below subsistence on $<5.6$ ha of land, and as this study revealed that smallholders are more likely to participate in tree planting projects and have an average tree density six times that of large farms, they should be a focus for tree planting projects in the region (Camagnari 2008, Berdegue and Fuentealba 2011). Although they control such a small proportion of land, tree-planting projects could achieve tree saturation in these plots with less investment, providing diverse and more sustainable sources of incomes to those most in need, parent seed sources for passive regeneration, increased connectivity, and other environmental services. As farmers already have experience and prefer planting species for wood, and as the trees cut by stakeholders and loggers demonstrate evidence of the ready market for native timber, this would be another appropriate focus for tree planting promotion in this region.

Although there is a market demand for timber, the amount of illegal extraction from the riparian area, as well as the limited number of trees cut from private lands within the mandatory permit system demonstrates a lack of enforcement, and perhaps the overall unenforceability, of the current forestry laws within the entire landscape matrix. These unfair laws, along with distance to market and lack of knowledge, inhibit access to 
wider trade and increased revenue (Detlefsen and Scheelje 2012). A decrease in restrictive, bureaucratic and punitive legal regulations could increase interest in managing trees (de Sousa et al 2106). However, the extractive accessibility and lack of enforcement in the riparian area should also be considered, as it may impede reforestation efforts along privately-held landscape elements, giving owners little incentive to go through the costs of growing trees on their own property when they are freely available elsewhere (Santos-Martin 2011). This demonstrates that while farmers make individual on-farm tree cover management decisions, they are also influenced by landscape management (or lack thereof), factors which should be considered when tree-planting projects are implemented. This study reveals the necessity of going beyond trees on farms, assessing interactions, transitions and emergence of tree cover in all elements of this formerly deforested landscape (Eriksson and Ehrlén 2001).

\section{Conclusion}

While this study demonstrates tree diversity and density similarities with other Central American tropical dry agricultural matrices, several unique contributions are made, documenting the differences between self-motivated and project-promoted tree plantings, regional differences in dominant species, farmer preferences and uses, and factors influencing tree adoption demonstrate the necessity of site-specific landscape management practices, including prospective tree planting projects. The original TDF was almost completely deforested in the cotton boom of the 1960s-70s, which was replaced by sugar expansion from the 1960s-1980s, and again from 1990 to 2015, and to a smaller extent peanut production. From this low baseline, gleaned from anecdotal evidence and verified by Google Earth, trees are now more evident in the landscape. The 
principle sources of trees are on farms, with the vast majority planted by the farmers themselves, entirely self-motivated, as live fences, wood for construction, and for fruit. Tolerated volunteers form the second major source, followed by project-planted trees. Two plantations of teak and eucalyptus respectively occupy $1.96 \%$ and $16.8 \%$ of the landscape with dense plantings of exotic species that inhibit recovery of native species. Finally, the spontaneous recovery of the riparian forest has contributed new connectivity, thus the landscape now has modest tree cover. These trends are promising, and the motivation of farmers to plant trees seems continuous as evident by the most recent Peace Corps project. Although this study did not directly measure other forms of biodiversity and environmental services provided by this moderately treed landscape, it can be assumed that the advantages described in the literature also hold true here, that birds, insects and small mammals find some modest habitat in this landscape. However, this modest recovery could be threatened by the proposed expansions of export agriculture crops, so small projects should encourage further plantings to diversify income sources of smallholders, and increase climate change resilience.

As farmers demonstrably value and are driven to plant trees without external incentives, projects should not necessarily depend on monetary stimulus like PES, which can lead to dependency, lack of continuity or unwillingness to participate if assistance is withdrawn (Current and Scherr 1995). This is not to preclude all planting interventions, rather to suggest that already extant stakeholder preferences and practices like live fencing can be supplemented with only training and basic materials as explicitly requested by participants, rather than imposing costly or inappropriate project preferences, capitalizing on local knowledge while increasing stakeholder accountability. 
While timber is an expressed value, it should not be the exclusive focus of tree planting initiatives, as there appear to be diverse opportunities to increase trees within the agricultural mosaic. Tree plantings should be tailored to stakeholder preferences, focus on smallholders and on native species suggested by stakeholders and valued for multiple uses to maximize the economic, social and environmental benefits provided. In order to encourage success in these plantings, the enforceability of current forestry laws should be evaluated, working with communities perhaps to self-police and limit extraction from crucial riparian corridors. This demonstrates the necessity of a wider, landscape approach to tree planting initiatives, considering not just trees on farms but tree cover, interactions, and transitions occurring in all landscape elements of the agricultural matrix. 


\section{LIST OF REFERENCES}

Andrade, H.J., Brook, R., Ibrahim M. (2008). Growth, production and carbon sequestration of silvopastoral systems with native timber species in the dry lowlands of Costa Rica. Plant Soil, (308): 11-22.

Achten, W., Navin, M.J.S,. Muys, B., Mathijs, E., Vantomme P. (2014). Opportunities and constraints of promoting new tree crops- Lessons learned from Jatropha. Sustainability, 6 (6): 3213-3231.

Aguilar, S., Condit, R. (2001). Use of native tree species by an Hispanic community in Panama. Economic Botany, 55 (2): 223-235.

Alcom, P.J., Pyttel, P., Bauhus, J., Smith, R.G.B., Thomas, D., James, R., Nicotra, A. (2007). "Effects of initial planting density on branch development in 4-year-old plantation grown Eucalyptus pilularis and Eucalyptus cloeziana trees." Forest Ecology and Management. 252: 41-51.

Ardila Rios, A., Moncada, B., Lücking, R. (2015). "Epiphyte homogenization and dediversification on alien Eucalyptus versus native Quercus forest in the Colombian Andes: a case study using lirellate Graphidaceae lichens." Biodiversity Conservation, 24 (5): 1239-1252.

Ashraf, J., Pandey, R., Jong, W., Nagar B. (2015). Factors influencing farmers' decisions to plant trees on their farms in Uttar Pradesh, India. Small-scale Forestry. 14: 301-313.

Atchison, J., and Head, L. (2013). Eradicating bodies in invasive plant management. SAGE Journals. 31.6: 951-968.

Barrance, A.J., Flores, L. Padilla E., Gordon J.E., Schreckenberg, K. (2003). Trees and farming in the dry zone of southern Honduras I: campesino tree husbandry practices. Agroforestry Systems, 59 (2): 87-106.

Bastien-Henn, S., Park, Ashton, M., Messier, C. (2010). Biomass distribution among tropical tree species grown under differing regional climates. Forest Ecology and Management, 260 (3): 403-410.

Benegas, L., Ilsted, U., Roupsard, O., Jones J., Malmer A. (2013). Effects of trees on infiltrability and preferential flow in two contrasting agroecosystems in Central America. Agriculture Ecosystems and Environment, 183: 185-196

Benjamin, K., Bouchard, A., Domon, G. (2008). Managing abandoned farmland: the need to link biological and sociological aspects. Environmental Management. 42.4: 603-619

Berdegue, J. A., and Fuentealba, R. (2011). Latin America: The state of smallholders in agriculture. International Fund for Agricultural Development. Rome, Italy. 
Boley, J. D., Drew, A. P., Andrus R.E. (2009). Effects of active pasture, teak (tectona grandis) and mixed native plantations on soil chemistry in Costa Rica. Forest Ecology and Management, 257 (1): 2254-2261.

Calvo-Alvarado, J, McLennan, B., Sanchez-Azofeifa, A., Garvin, T. (2009). Deforestation and forest restoration in Guanacaste, Costa Rica: Putting conservation policies in context. Forest Ecology and Management, 258: 931-940

Camagnari, M. (2008). La agricultura familiar en America Latina: Problemas del Desarollo. Revista Latinoamerica de Economia, 39: 153.

Chacko, K. C., Chandrasekhara, P. P. K. (1997). Storage and hot-water treatments enhance germination of Guanacaste (Enterolobium cyclocarpium) seeds. International Tree Crops Journal, 9 (2):103-107.

Cuenta Reto del Milenio (2008). Boletin Electronico. Cuenta Reto del Milenio Nicaragua. 102 Web. 6 Mar. 2016.

Current, D., Scherr S.J. (1995). Farmer costs and benefits from agroforestry and farm forestry projects in Central America and the Caribbean: implications for policy. Agroforestry Systems, 30: 87-103.

Daily, G.C. Caballos, G., Pacheco, J., Suzan, G., Sanchez-Azofelfa, A. (2003). Countryside biogeography of neo-tropical mammals: Conservation opportunities in agricultural landscapes of Costa Rica. Conservation Biology, 17: 1814-1825.

De Oliveira Cardoso, M., Pedrosa, E. M.., Mario, M., Silva, E., Enio, F., de Barros P. A. (2012). Effects of soil mechanical resistance on nematode community structure under conventional sugarcane and remaining Atlantic forest. Environmental Monitoring and Assessment, 20 (2): 3529-3544.

De Sousa, K. F. D., Detlefsen, G., de Melo, E., Füho, V., Tobar, D., Casanoves, F. (2016). Timber yield from smallholder agroforestry systems in Nicaragua and Honduras. Agroforestry Systems, 90: 207-218.

Detlefsen G., Scheelje, M. (2012). Las normativas legales y el aprovechamiento de la madera en fincas: Produccion de madera ensistemas agroforestales de Centroamerica. Centro Agronomico Tropical de Investigacion y Ensenanza (CATIE), Turrialba, Costa Rica: 211-242.

Diaz, S., Tilman, D., Fargione, J. (2005). Biodiversity regulation of Ecosystem Services. R. Hassan, R. Scholes, N. Ash (Eds.). Ecosystems and Human Well-being: Current State and Trends: findings from the condition and trends working group, vol. 1: The millennium ecosystem assessment series. Retrieved from Ecosystems and Human Wellbeing Current State and Trends. 
Dymond, C. C., Tedder, S., Spittlehouse, D. L., Raymer, B., Hopkins, K., McCallion, K. (2014). Diversifying managed forests to increase resilience. Canadian Journal of Forest Research, 44 (10): 1196.

Dzikiti, S., Gush, M.B., LeMaitre, D.C., Maherry, A., Jovanovic, N.Z., Ramoelo, A., Cho, M.A. (2016). Quantifying potential water savings from clearing invasive alien Eucalyptus camaldulensis using in situ and high resolution remote sensing data in the Berg River Catchment, Western Cape, South Africa. Forest Ecology and Management, 361 (1): 69-80.

Ellison, D., Futter, M.N., Bishop, K. (2012). On the forest cover-water yield debate: from demand to supply-side thinking. Global Change Biology, 18: 806-820.

Eriksson O, Ehrlén J. Landscape fragmentation and the viability of plant populations. In: Silvertown J. ,Antovics J. (2001) Integrating ecology and evolutions in a spatial context. Blackwell Science, Oxford: 157-175.

Evans, J., Turnbull, J. W. (2004). Plantation Forestry in the Tropics. Oxford University Press, Oxford.

Fischer, J., Zerger, A., Gibbons, P., Stott, J., Law, B.S. (2010). Tree decline and the future of Australian farmland biodiversity. Proceedings of the National Academy of Sciences of the United States of America, 107: 19597-19602

Food and Agricultural Organization of the United Nations (FAO). (2001). Global Forest Resources Assessment 2000. FAO, Rome.

Food and Agriculture Organization of the United Nations (FAO). (2013). Advancing agroforestry on the policy agenda: A guide for decision-makers. Agroforestry Working Paper no. 1. Rome, 1-35.

Forest Stewardship Council (FSC). (2004). Perspectives on plantations: A review of the issues facing plantation management. FSC, Bonn.

Foundjern-Tita, D., Degrande, A., Tchoundjeu, Z., Speelman, S., D’Haese, M., Asaah, E., van Huylenbroeck, G., van Damme, P., Ndoye, O. (2013). Policy and legal frameworks governing trees: Incentives or disincentives for smallholder tree planting decisions in Cameroon? Small-scale Forestry, 12 (3): 489-505.

Fuchs, E. J., Lobo, J. A., Quesada, M. (2003). Effects of forest fragmentation and flowering phenology on the reproductive and mating patterns of the tropical dry forest tree Pachira quinata. Conservation Biology, 17 (1): 149-157. 
Galicia, L., Zarco-Arista, A. E., Mendoza-Robles, K. I., Palacio-Prieto, J. L., GarciaRomero, A. (2008). Land use/cover, landforms and fragmentation patterns in a tropical dry forest in southern Pacific region of Mexico. Singapore Journal of Tropical Geography, 29 (2): 137-154.

Galloway, G., Ugalde, L., Vazquez W. (2001). Importance of density reductions in tropical plantations: Experiences in Central America. Forests, Trees, and Livelihoods, 11 (3): 217-232.

Galvez, N., Hernandez, F., Laker, J., Gliabert, H., Petitpas, R., Bonacio, C., Gimona, A., Hester, A., Macdonald, D. (2013). Forest cover outside protected areas plays an important role in the conservation of the vulnerable guiña Leopardus guigna. Fauna and Flora International, 47 (12): 251-258.

Garen, E.J., Saltonstall, K., Slusser, J. L., Mattias, S., Ashton, M. S., Hall, J. S. (2009). An evaluation of farmers' experiences planting native trees in rural Panama: implications for reforestation with native species in agricultural landscapes. Agroforestry Systems, 76: 219-236.

Garen, E.J., Saltonstall, K., Slusser, J. L., Mattias, S., Ashton, M. S., Hall, J. S. (2011). The tree planting and protecting culture of cattle ranchers and small-scale agriculturalists in rural Panama: Opportunities for reforestation and land restoration. Forest Ecology and Management, 261 (10): 1684-1695.

Gerber, J. F. (2010). Conflicts over industrial tree plantations in the South: Who, how and why? Global Environmental Change, 21 (1): 165-176.

Gillespie, T. W., Grijalva, A., Farris, C. N. (2000). Diversity, composition, and structure of tropical dry forests in Central America. Plant Ecology, 147: 37-47.

Gillies, C. S., St. Clair, C. C. (2008). Riparian corridors enhance movement of a forest specialist bird in fragmented tropical forest. Proceedings of the National Academy of Sciences, 105 (50): 19774-19779.

Godfray, H.C., Beddington, J.R., Crute, I.R., Haddad, L., Lawrence, D., Muir, J.F., Pretty, J., Robinson, S., Thomas, S. M., Toulmin C. (2010). Food Security: the challenge of feeding 9 billion people. Science, 32: 812-818.

Gordon, J. E., Hawthorne, W. D., Reyes-Garcia, A., Sandoval, G., Barrance A. J. (2004).

Assessing landscapes: a case study of tree and shrub diversity in the seasonally dry tropical forests of Oaxaca, Mexico and southern Honduras. Biological Conservation, 17 (4): 429-442. 
Gourdji, S., Läderach, P., Martinez Valle, A., Zelaya Martinez, C., Lobell, D. B. (2015). Historical climate trends, deforestation, and maize and bean yields in Nicaragua. Agricultural and Forest Meteorology, 200: 270-281.

Grinevskii, S.O., Novoselova, M.V. (2011). Regularities in the formation of groundwater infiltration recharge. Water Resources, 38: 175-186

Griscom, H. P., Ashton, M.S., Berlyn, G. P. (2005). Seedling survival and growth of native tree species in pastures: Implications for tropical dry forest rehabilitation in central Panama. Forest Ecology and Management, 216 (1-3): 306-318.

Griscom, H.P., Ashton, M.S. (2011). Restoration of dry tropical forests in Central America: a review of pattern and process. Forest Ecology and Management, 261: 15641579 .

Griscom, H. O., Connelly, A. B., Ashton, M. S., Wishnie, M. H. (2011). The structure and composition of a tropical dry forest landscape after land clearance; Azuero Peninsula, Panama. Journal of Sustainable Forestry, 30 (8): 756-774.

Haglund, E., Mdjeunga, J., Snook, L., Pasternak, D. (2011). Dry land tree management for improved household livelihoods: Farmer managed natural regeneration in Niger. Journal of Environmental Management, 92 (7): 1696-1705.

Haile, S. G., Nair, V., Ramachandran, P.K. (2010). Contribution of trees to carbon storage in soils of silvopastoral systems in Florida, USA." Global Change Biology, 16: 427-438.

Hall, J. S., Love, B. E., Garen, E. J., Slusser, J. L., Saltonstall, K., Mathias, S., van Breuge, M., Ibarra, D., Bork, E. W., Spaner, D., Wishnie, M. H., Ashton, M. S. (2010). Tree plantations on farms: Evaluating growth and potential for success. Forest Ecology and Management, 261 (10): 1675-1683.

Hall, J. S., Ashton, M. S., Green, E. J., Jose, S. (2011). The ecology and ecosystem services of native trees: Implications for reforestation and land restoration in Mesoamerica. Forest Ecology and Management, 261 (10): 1553-1557.

Hartley, M. (2002). Rationale and methods for conserving biodiversity in plantation forests. Forest Ecology and Management, 155: 81-95.

Harvey, C. A., Haber, W. A. (1999). Remant trees and the conservation of biodiversity in Costa Rican pastures. Agroforestry Systems, 44: 37-68.

Harvey, C. A. (2000). Colonization of agricultural windbreaks by forest trees: effects of connectivity and remnant trees. Ecological Applications, 10 (6): 1762-1773. 
Harvey, C.A, Villanueva, C., Vallacis, J., Chacón, M., Muñoz, D., López, M., Ibrahim, M., Gomez, R., Taylor, R., Martinez, J., Navas, A., Shaenz, J., Sanchez, D., Medina, A., Vilchez, S., Hernandez, B., Perez, A., Ruiz, F., Lopez, F., Lang, L., Sinclair, F.L. (2005). Contribution of live fences to the ecological integrity of agricultural landscapes." Agriculture, Ecosystems \& Environment, 111: 200-230.

Harvey C. A., Komar, O., Chazdon, R., Ferguson, B. G., Finegan, B., Griffith, D., Martinez-Ramos, M., Morales, H., Nigh, R., Soto-pinto, L., Van Breugel, M., Wishnie, M. (2008). Integrating agricultural landscapes with biodiversity conservation in the Mesoamerican hotspot. Conservation Biology, 22 (1): 8-15.

Harvey, C. A., Villanueva, C., Esquivel, H., Gomez, R., Ibrahim, M., Lopez, M., Martinez, J., Muñoz, D., Restrepo, C., Saenz, J. C., Villacis, J., Sinclair, F. L. (2011). Conservation value of dispersed tree cover threatened by pasture management. Forest Ecology and Management, 261 (10): 1664-1674.

Healey, S. P., Gara, R. J. (2003). The effect of a teak (Tectona grandis) plantation on the establishment of native species in an abandoned pasture in Costa Rica. Forest Ecology and Management, $176(1): 497-507$.

Hocking, D., Hocking, A., Ray, I., Roy, I.(1997). Trees in Bangladesh paddy fields and homesteads: the future of forestry in crowded countries. The Commonwealth Forestry Review, 76 (4): 255-260.

Horlings, L.G., Marsden, T.K. (2011). Towards the real green revolution? Exploring the conceptual dimensions of a new ecological modernization of agriculture that could 'feed the world'. Global Environmental Change, (Web.) 6 March 2016.

International Finance Corporation. (2007). Monte Rosa Sugar: Environmental and Social Review Summary. World Bank Group, (web) Dec. 2015.

Invasive Species Compendium. (2014). Eucalyptus camaldulensis, historical introduction. Invasive Species Compendium, (Web). 12 Apr 2016.

Janzen, D. H. (1998). Tropical dry forests: The most endangered major tropical ecosystem. Biodiversity. Ed. Wilson, E. O., Peter, F.M. Washington D.C.: National Acadamies Press. NCBI Resources, (Web). 21 Dec. 2015.

Käffer, M. L, Ganade, G., Marcelli, M. (2009). Lichen diversity and composition in Araucaria forests and tree monocultures in Southern Brazil. Biodiversity Conservation, 18: $3545-3561$.

Keating B.A., Carberry, P.S., Bindraban, P.S., Asseng, S., Meinke, H., Dixon, J. (2010). Eco-efficient agriculture: concepts, challenges and opportunities. Crop Science, 50: 109119. 
Langkeek, A. G., Kindt, R., van der Maesen, L. J. G., Simons, A. J., van Oijen, D. C. C. (2005). Tree density and germplasm source in agroforestry ecosystems in Meru, Mount Kenya. Genetic Resources and Crop Evolution, 52: 709-721.

Law 462. El presidente de la Republica de Nicaragua. La Asamblea Nacional de la Republica de Nicaragua. Ley de Conseracion, Fomento, y Desarollo Sostenible del Sector Forestal. Seccion 5, Acto 27. 26 Junio, 2003.

Lees, A. C., Peres, C. A. (2008). Conservation value of remnant riparian forest corridors of varying quality for Amazonian birds and mammals. Conservation Biology, 22 (2): 439-449.

Love, B., Spaner, D. (2005). A survey of small-scale farmers using trees in pasture in Herrera Province, Panama. Journal of Sustainable Forestry, 20 (3): 37-65.

Love, B. E., Bork, E. W., Spaner, D. (2009). Tree seedling establishment in living fences: a low-cost agroforestry management practice for the tropics. Agroforestry Systems, 77: $1-8$.

Malla, Y.B. (2012). Farmers tree management strategies in a changing rural economy, and factors influencing decisions on tree growing in Nepal. International Tree Crops Journal, 10 (3): 247-266.

Malmer, A., Murdiyarso, D., Bruijnzeel, L.A., Ilstedt, U. (2010). Carbon sequestration in tropical forests and water: a critical look at the basis for commonly used generalizations. Global Change Biology, 16: 599-604.

Maluenda, J., Araquistain, R., Jensen, N., Nilsson, M., Pérez, D. (2002). Guia de especies forestales de Nicaragua. Ministerio del Ambiente y los Recursos Naturales (MARENA), Managua, Nicaragua.

Manning, A. D., Fischer, J., Lindenmayer, D. B. (2006). Scattered trees are keystone structures- Implications for conservation. Biological Conservation, 132 (3): 311-321.

McGarigal K., Cushman, S.A. (2002). Comparative evaluation of experimental approaches to the study of habitat fragmentation effects. Ecological Approaches, 12: 335345.

Meijaard, E., Abram, N. K., Wells, J. A., Pellier, A. S., Ancrenaz, M., Gaveau, D. V. A., Runting, R. K., Mengersen, K. (2013). People's perceptions about the importance of forests on Borneo. PLoS One, 8 (9): e73008

Mekoya, A., Ostling, S. J., Fernandez-Rivera, S., Van der Zipp, A. J. (2008). Farmers' perceptions about exotic multipurpose fodder trees and constraints to their adoption. Agroforestry Systems, 73: 141-153. 
Mendoza, S. V., Harvey, C. A., Sanchez, J. C., Casanoves, F., Carvajal, J. P., Gonzalez Villalobos, J., Hernandez, B., Medina, A., Montero, A., Sanchez Merlo, D., Sinclair, F. L. (2014). Consistency in bird use of tree cover across tropical agricultural landscapes. Ecological Applications, 24: 158-168.

Millar, C. J., Stephenson, N. L., Stephens, S. L. (2007). Climate change and forests of the future: Managing in the face of uncertainty. Ecological Applications, 17 (8): 2145-2151.

Millennium Challenge Corporation. (2010). Monitoring and Evaluation Plan Nicaragua. Nicaragua Compact, 65. (Web) 6 Mar. 2016.

Montagnini, F. (2005). Plantaciones forestales con especies nativas. Una alternativa para la produccion de madera y la provision de servicios ambientales. Rev Recursos Naturales y Ambientales, 43: 26-33.

Naranjo de la F., J., Salgado-Garcia, S., Lagunes-Espinoza, L.C., Carrillo-Avila, E., Palma-Lopez, D.J. (2006). Changes in the properties of a Mexincan Fluvisol following 30 years of sugarcane cultivation. Soil and Tillage Research, 86 (1): 160-167.

Nascimiento, H. E. M., Laurance, W. F. (2002). Total aboveground biomass in central Amazonian rainforests: a landscape-scale study." Forest Ecology and Management, 168 (1): $311-321$.

Newham, M., Fellow, C. S., Sheldon, F. (2010). Functions of riparian forest in urban catchments: a case study from sub-tropical Brisbane, Australia. Urban Ecosystems, 14: 165-180.

Mutua, A., Kindt, R., Lamnadass, R., Anthony, S.. (2009). Bombascopsis quinata. Agroforestree Database: A tree reference and selection guide, Version 4.0. (Web).

Pankaj, S., Lokeshwar, T., Mukesh, B., Vishnu, B. (2011). Review on Neem (Azadirachta indica): Thousand problems One solution. International Research Journal of Pharmacy, 2 (12): 97-102.

Pantaleon. (2010). Informe Social y Ambiental (cuarta parte). Pantaleon Sugar Holdings Company Limited, (Web) 12 March 2016.

Pares-Ramos, I. K., Gould, W. A., Aide, T.M. (2008). Agricultural abandonment, suburban growth, and forest expansion in Puerto Rico between 1991 and 2000. Ecology and Society, 13 (2): 1

Patzek, T. W., Pimentel, D. (2005) Thermodynamics of energy production from biomass. Critical reviews in Plant Sciences, 24 (5-6): 327-364. 
Pfund, J. L., Watts, J. D., Bussiere, M., Boucard, A., Bullock, R. M., Ekadinata, A., Dewi, S., Feintrenie, L., Levang, P., Rantala, S., Sheil, D., Heethorn Sunderland, T., C., Urech, Z. L. (2011). Understanding and integrating local perceptions of trees and forests into incentives for sustainable landscape management. Environmental Management, 48 (2): $334-349$.

Pineda, A. G. (2006). Flora útil etnobotánica de Nicaragua.” Ministerio del Ambiente y los Recursos Naturales (MARENA), (2006): 1-352.

Piotto, D. E. Viquez, F. Montagnini, M. Kaninnen. (2004). Pure and mixed forest plantations with native species of the dry tropics of Costa Rica: a comparison of growth and productivity. Ecological Management, 190: 359-372.

Place, F., Ajayi, O. C., Masters, E. (2011). Tree-based and other land management technologies for landscape restoration and livelihood in Africa. In: P. Dewees, F. Place, S.J. Scherr, C. Buss (principal authors). Investigating in trees and landscape restoration in Africa: What, where and how. Program on Forests (PROFOR), Washington DC.: 17-44.

Portillo-Quintero, A., Sanchez-Azofeifa, M., do Espirito-Santo, M. (2013). Edge influence on canopy openness and understory microclimate in two neotropical dry forest fragments. In: Sanchez-Azofeifa, M., Arturo, G., Powers, J. S., Quesada, M. (2013). Tropical Dry Forests in the America: Ecology, Conservation, and Management, CRC Press: 157-172.

Rhoades, C., Binkley, D. (1996). Factors influencing decline in soil pH in Hawaiian Eucalyptus and Albizia plantations. Forest Ecology and Management, 80 (1): 47-66.

Robinson. R. A., Sutherland, W.J. (2002). Post-war changes in arable farming and biodiversity in Great Britain. Journal of Applied Ecology, 39 (1): 157-176

Rojas-Sandoval, J., Acevedo-Rodriguez, P. (2014). Azadirachta indica, historical introduction. Invasive Species Compendium, (Web): 12 Apr 2016.

Rolim, S. G., Jesus, R. M., Nascimiento, H. E. M., do Couto, H. T. Z., Chambers, J. Q. (2005). Biomass change in an Atlantic tropical moist forest: the ENSO effect in permanent sample plots over a 22-year period. Oecologia, 142: 238-246.

Sabogal, C. (1992). Regeneration of Tropical Dry Forests in Central America, with Examples from Nicaragua. Journal of Vegetation Science, 3: 407-416.

Sagar, R, Singh, J. S. (2006). Tree density, basal area and species diversity in a disturbed dry forest of northern India: implications for conservation. Environmental Conservation. 33 (3): 256-262. 
Sandor, M. E., Chazdon, R. L. (2014). Remnant trees affect species composition but not structure of tropical second-growth forest. PLOS One, 9 (1): e83284.

Santos-Martin, F., Bertomeu, M., Noordwijk, M., Navarro, R. (2011). Understanding forest transition in the Philippines: main farm-level factors influencing smallholder's capacity and intention to plant native timber trees. Small-Scale Forestry, 11 (1): 47-60

Simons A. J, Stewart J. L. (1994). Gliricidia sepium. 30-48. In: Gutteridge R.C. and Shelton H.M. (eds), Fodder Tree Legumes in Tropical Agriculture, CAB International Walingford, U.K.

Song,I., Kim, I., Han, D. H., Byeon, M-S., Lee, J-K., Kang, M-S. (2011). Prioritizing locations for the riparian establishment based on spatiotemporal change of riparian forest area at a watershed scale. Paddy and Water Environment, 10: 49-58.

Spieran, G. K. (2010). Effects of groundwater-flow paths on nitrate concentrations across two riparian corridors. Journal of the American Water Resources Association, 46 (2): 246-260.

Suarez, A., Williams-Linera, G., Trejo, C., Valdez-Hernandez, J. I., Cetina-Alcala, V. M., Vibrams, H. (2012). Local knowledge helps select species for forest restoration in a tropical dry forest of central Veracruz, Mexico. Agroforestry Systems, 85: 35-55.

Tanaka, M. O., Fernandes, J. F., Suga, C. M., Hana, F. Y., Teixeira de Souza, A. L. (2015). Abrupt change of a stream ecosystem function along a sugarcane-forest transition: Integrating riparian and in-stream characteristics. Agriculture, Ecosystems \& Environment. 207 (1): 171-177.

Tarrasón, D., Urrutia, J. T., Ravera, F., Herrera, E., Andres, P. (2010). Conservation status of tropical dry forest remnants in Nicaragua: Do ecological indicators and social perception tally? Biodiversity Conservation, 19:813-827.

Tschamtke, T., Clough, Y., Wanger, T. C., Jackson, L., Motzke, I., Perfecto, I., Vandermeer, J., Whitbread, A. (2012). Global food security, biodiversity conservation and the future of agricultural intensification." Biological Conservation, 151 (1): 53-59.

Townsend, P. A., Levey, D. J. (2005). An experimental test of whether habitat corridors affect pollen transfer. Ecology, 86 (2): 466-475.

United Nations. (2010). Access to water and firewood. The world's women 2010: Trends and statistics. United Nations, New York: 145

USAID. (2010). Land rights and property rights: Nicaragua. Country Profiles. (Web): Dec. 2015. 
USDA Foreign Agricultural Service. (2013). Nicaragua: Sugar Annual Report 2013. GAIN Report: 1-7.

Vieira, D.L.M., Scariot, A. (2006). Principles of natural regeneration of tropical dry forests for restoration. Restoration Ecology, 14: 11-20.

Wassenaar,T. Gerber, P., Verburg, P. H., Rosales, M., Ibrahim, M., Steinfeld, H. (2007).

Projecting land use changes in the neotropics: the geography of pasture expansion into forest. Global Environmental Change, 17: 86-104

Whitehead, J. C., Pattanayak, S. K., Van Houtven, G. L., Gelso, B. R. (2008) Combining revealed and stated preference data to estimate the nonmarket value of ecological services: An assessment of the state of the science. Journal of Economic Surveys, 22 (5): 872-908.

Williams-Linera, G., Lorea, F. (2009). Tree species diversity driven by environmental and anthropogenic factors in tropical dry forest fragments of central Veracruz, Mexico. Biodiversity Conservation, 18 (12): 3269-3293.

Wishnie, M., Dent, D., Mariscal, E., Deago, J., Cedeno, N., Ibarra, D., Condit, R., Ashton, P. M. S. (2007). Initial Performance and reforestation potential of 24 tropical tree species planted across a precipitation gradient in the Republic of Panama. Forest Ecology and Management, 243: 39-49

World Bank. (2014). GNI per capita Atlas Method (current US\$. World Development Indicators, (Web): 4 April 2015.

World Bank. (2007). World Development Report. Agriculture for Development, Washington D.C. (Web): 9 March, 2016.

World Bank. (2008). Implementation completion and results report for the Integrated Silvopastoral Approaches to Ecosystem Management Project in Colombia, Costa Rica, and Nicaragua. Environmentally and Socially Sustainable Development. Central American Department, Latin America and Caribbean Region, 1-90.

Zomer, RJ, Trabucco, A., Coe, R., Place, F., van Noordwijk, M., Xu, J. C. (2014). Trees on farms: an update and reanalysis of agroforestry's global extent and socio-ecological characteristics. Working Paper 179. Bogor, Indonesia: World Agroforestry Centre (ICRAF) Southeast Asia Regional Program. 


\section{APPENDICES}

Table 7: Species Inventoried and Their Uses

\begin{tabular}{|c|c|c|c|c|c|c|c|}
\hline \multirow{2}{*}{$\begin{array}{l}\text { Common } \\
\text { Name }\end{array}$} & \multirow[t]{2}{*}{ Species } & \multirow{2}{*}{\begin{tabular}{|l} 
Naturally \\
Sprouted \\
trees
\end{tabular}} & \multicolumn{2}{|c|}{ Deliberately planted } & \multirow{2}{*}{\begin{tabular}{|l} 
Total on \\
Private \\
Property
\end{tabular}} & \multirow{2}{*}{$\begin{array}{l}\text { Native }(\mathrm{N}) \\
\text { or } \\
\text { Introduced } \\
(\mathrm{I})\end{array}$} & \multirow{2}{*}{$\begin{array}{l}\text { Reasons } \\
\text { Ranked }\end{array}$} \\
\hline & & & $\begin{array}{l}\text { Owner } \\
\text { Preference }\end{array}$ & \begin{tabular}{|l|} 
Project \\
Preference
\end{tabular} & & & \\
\hline $\begin{array}{l}\text { Acacia } \\
\text { amarilla }\end{array}$ & Senna siamea & 6 & 1 & & 7 & II & PA \\
\hline Achiote & Bixa orellana & 0 & 9 & & 9 & $\mathrm{~N}$ & $\mathrm{~F}, \mathrm{PA}$ \\
\hline Aguacate & Persea americana & 0 & 129 & & 129 & $\mathrm{~N}$ & $\mathrm{~F}, \mathrm{PA}, \mathrm{M}$ \\
\hline Algodon & Gossypium hirsutum & 0 & 1 & & 1 & I & PA \\
\hline Almendro & Andira inermis & 3 & 35 & & 38 & $\mathrm{~N}$ & PA, FW \\
\hline Anona & Annona reticulata L. & 15 & 7 & & 22 & $\mathrm{~N}$ & $\mathrm{~F}, \mathrm{FW}$ \\
\hline Bienteveo & Gurania coccinea & 0 & 6 & & 6 & $\mathrm{~N}$ & PA \\
\hline Cacao & $\begin{array}{l}\text { Theobroma cacao } \\
\text { trinitaria }\end{array}$ & 0 & 0 & 260 & 260 & $\mathrm{~N}$ & $\mathrm{~F}, \mathrm{PA}$ \\
\hline Caimito & $\begin{array}{l}\text { Chrysophyllum } \\
\text { cainito }\end{array}$ & 1 & 11 & & 12 & $\mathrm{~N}$ & $\mathrm{~F}, \mathrm{LF}$ \\
\hline Canfunzia & $\begin{array}{l}\text { Achatocarpus } \\
\text { nigracans }\end{array}$ & 18 & 3 & & 21 & $\mathrm{~N}$ & $\mathrm{PA}, \mathrm{M}$ \\
\hline Caoba & $\begin{array}{l}\text { Swietenia humilis } \\
\text { Zucc. }\end{array}$ & 10 & 9 & & 19 & $\mathrm{~N}$ & $\mathrm{~W}, \mathrm{PA}$ \\
\hline Carao & Cassia grandis & 36 & 0 & & 36 & $\mathrm{~N}$ & $\mathrm{~W}, \mathrm{PA}, \mathrm{T}$ \\
\hline Cedro Real & Cedrela odorata & 108 & 23 & & 131 & $\mathrm{~N}$ & $\begin{array}{l}\text { W, PA, } \\
\text { FW }\end{array}$ \\
\hline Ceiba & Ceiba pentandra & 157 & 2 & & 159 & $\mathrm{~N}$ & $\begin{array}{l}\text { W, PA, } \\
\text { LF, FW }\end{array}$ \\
\hline Chilamate & Ficus goldmanii & 46 & 0 & & 46 & $\mathrm{~N}$ & PA, LF, E \\
\hline Coco & Cocos nucifera & 0 & 235 & & 235 & I & $\mathrm{F}, \mathrm{M}$ \\
\hline Cortez & $\begin{array}{l}\text { Tabebuia ochracea } \\
\text { ssp. neochrysantha }\end{array}$ & 44 & 2 & & 46 & $\mathrm{~N}$ & PA, E, W \\
\hline Cuajilote & Parmentiera aculeata & 2 & 0 & & 2 & $\mathrm{~N}$ & PA \\
\hline Cuajiniquil & $\begin{array}{l}\text { Inga spuria H \& B or } \\
\text { Inga vera }\end{array}$ & 15 & 0 & & 15 & $\mathrm{~N}$ & PA, W \\
\hline $\begin{array}{l}\text { Espino Cacho } \\
\text { Buey }\end{array}$ & Vachelia cornigera & 33 & 0 & & 33 & $\mathrm{~N}$ & LF, E \\
\hline Eucalypto & Eucalyptus sp. & 2 & 68 & 2000 & 2070 & $\mathrm{I}$ & $\begin{array}{l}\text { W, LF, M, } \\
\text { PA }\end{array}$ \\
\hline Frutipan & Artocarpus altillis & 0 & 5 & & 5 & $\mathrm{I}$ & $\mathrm{F}$ \\
\hline Grapefruit & Citrus paradisi & 0 & 18 & & 18 & I & $\mathrm{F}, \mathrm{M}$ \\
\hline Grosea & Phyllanthus acidus & 4 & 1 & & 5 & I & $\mathrm{F}$ \\
\hline $\begin{array}{l}\text { Guacimo de } \\
\text { ternero }\end{array}$ & Guazuma ulmifolia & 445 & 2 & & 447 & $\mathrm{~N}$ & $\begin{array}{l}\text { FL, LF, } \\
\text { PA, FW }\end{array}$ \\
\hline Guanabana & Annona muricata & 17 & 17 & & 34 & $\mathrm{~N}$ & $\mathrm{~F}, \mathrm{PA}$ \\
\hline $\begin{array}{l}\text { Guanacaste } \\
\text { Blanco }\end{array}$ & $\begin{array}{l}\text { Albizia niopoides } \\
\text { Spruce ex Benth }\end{array}$ & 89 & 0 & & 89 & $\mathrm{~N}$ & $\begin{array}{l}\text { W, PA, } \\
\text { FW, LF }\end{array}$ \\
\hline
\end{tabular}




\begin{tabular}{|c|c|c|c|c|c|c|c|}
\hline $\begin{array}{l}\text { Guanacaste } \\
\text { Negro }\end{array}$ & $\begin{array}{l}\text { Enterolobum } \\
\text { cyclocarpum }\end{array}$ & 147 & 0 & & 147 & $\mathrm{~N}$ & $\begin{array}{l}\text { W, PA, } \\
\text { FW, LF }\end{array}$ \\
\hline Guarumo & Cecropia peltata L. & 57 & 0 & & 57 & $\mathrm{~N}$ & $\begin{array}{l}\text { LF, PA, E, } \\
T\end{array}$ \\
\hline Guayaba & Psidium guajava & 83 & 31 & & 114 & $\mathrm{~N}$ & $\begin{array}{l}\text { F, FW, } \\
\text { PA, LF }\end{array}$ \\
\hline Guayabilla & Alibertia edulis & 31 & 6 & & 37 & $\mathrm{~N}$ & $\begin{array}{l}\text { F, FW, } \\
\text { PA, LF, E }\end{array}$ \\
\hline Guiscoyol & Bactris guineensis & 5 & 0 & & 5 & $\mathrm{~N}$ & F, LF \\
\hline Hombro Caido & & 0 & 2 & & 2 & & PA \\
\hline Icaco & Chrysolbalanus icaco & 0 & 4 & & 4 & $\mathrm{~N}$ & $\mathrm{~F}$ \\
\hline Jicaro & Crescentia alata & 434 & 19 & & 453 & $\mathrm{~N}$ & FL, F, LF \\
\hline Jilinjoche & $\begin{array}{l}\text { Pseudobombar } \\
\text { ellipticum }\end{array}$ & 1 & 0 & & 1 & $\mathrm{~N}$ & $\mathrm{E}$ \\
\hline Jocote & Spondias purpurea & 19 & 441 & & 460 & $\mathrm{~N}$ & F, LF \\
\hline Jocote Jobo & Spondia mombin L. & 4 & 0 & & 4 & $\mathrm{~N}$ & $\mathrm{~F}$ \\
\hline Jupiter & $\begin{array}{l}\text { Legerstroemia } \\
\text { speciosa }\end{array}$ & 0 & 1 & & 1 & I & PA \\
\hline Laurel & Cordia allodora & 768 & 67 & & 835 & $\mathrm{~N}$ & $\begin{array}{l}\text { W, PA, } \\
\text { LF, FW }\end{array}$ \\
\hline $\begin{array}{l}\text { Laurel de la } \\
\text { India }\end{array}$ & Ficus benjamina & 1 & 1 & & 2 & $\mathrm{I}$ & PA, E \\
\hline Lima & Citrus aurantiifolia & 0 & 1 & & 1 & $\mathrm{I}$ & $\mathrm{F}$ \\
\hline Limon & Citrus aurantifolia & 11 & 233 & & 244 & $\mathrm{I}$ & $\mathrm{F}, \mathrm{M}$ \\
\hline Limon chino & Citrus meyeri & 0 & 7 & & 7 & $\mathrm{I}$ & $\mathrm{F}$ \\
\hline $\begin{array}{l}\text { Limon } \\
\text { mandarina }\end{array}$ & Citrus nobili & 0 & 46 & & 46 & I & F, PA \\
\hline Limonaria & Murraya paniculata & 1 & 2 & & 3 & I & $\mathrm{M}$ \\
\hline $\begin{array}{l}\text { Llamara del } \\
\text { bosque }\end{array}$ & $\begin{array}{l}\text { Spathodea } \\
\text { campanulata }\end{array}$ & 0 & 1 & & 1 & I & PA \\
\hline Madero Negro & Gliricidia sepium & 438 & 0 & 523 & 961 & $\mathrm{~N}$ & $\begin{array}{l}\text { W, PA, } \\
\text { FW, LF, } \\
\text { FL, T }\end{array}$ \\
\hline Madroño & $\begin{array}{l}\text { Calycophyllum } \\
\text { candidissimum DC }\end{array}$ & 47 & 0 & 33 & 80 & $\mathrm{~N}$ & PA, W \\
\hline Malinche & Delonix regia & 68 & 0 & & 68 & I & PA, LF \\
\hline Mamoncillo & Melicoccus bijugatus & 69 & 36 & & 105 & I & $\mathrm{F}, \mathrm{Pa}$ \\
\hline Mango & Mangifera indica & 225 & 292 & & 517 & I & $\begin{array}{l}\text { F, PA, FL, } \\
\text { FW, W, E }\end{array}$ \\
\hline Manzano & Crataeva tapia & 2 & 0 & & 2 & $\mathrm{~N}$ & PA, F, E \\
\hline Marango & Moringa oleifara & 4 & 0 & 32 & 36 & $\mathrm{I}$ & $\mathrm{M}, \mathrm{FL}, \mathrm{PA}$ \\
\hline Marañon & $\begin{array}{l}\text { Anacardium } \\
\text { occidentalis }\end{array}$ & 0 & 42 & & 42 & $\mathrm{I}$ & $\mathrm{F}, \mathrm{M}, \mathrm{PA}$ \\
\hline Meembro & Averrhoa bilampi & 1 & 15 & & 16 & $\mathrm{~N}$ & F, PA \\
\hline Melina & Gmelina arborea & 1 & 91 & & 92 & I & W \\
\hline $\begin{array}{l}\text { Melocoton/ } \\
\text { carambola }\end{array}$ & Averrhoa carambola & 0 & 4 & & 4 & $\mathrm{~N}$ & $\mathrm{~F}, \mathrm{PA}$ \\
\hline Michiguiste & Pithecellobium dulce & 114 & 0 & & 114 & $\mathrm{~N}$ & W,PA, \\
\hline
\end{tabular}




\begin{tabular}{|c|c|c|c|c|c|c|c|}
\hline & & & & & & & FW \\
\hline Muñeco & Cordia collococco & 15 & 0 & & 15 & $\mathrm{~N}$ & $\begin{array}{l}\text { PA, FW, } \\
\text { W }\end{array}$ \\
\hline Nancite & Byrsonima crassifolia & 20 & 108 & & 128 & $\mathrm{~N}$ & F, PA \\
\hline Naranja & Citrus sinesis & 11 & 264 & & 275 & I & $\mathrm{F}, \mathrm{M}$ \\
\hline $\begin{array}{l}\text { Narciso } \\
\text { amarillo }\end{array}$ & $\begin{array}{l}\text { Thevetia nerifolia } \\
\text { Juss. Ex Steud. }\end{array}$ & 0 & 5 & & 5 & $\mathrm{~N}$ & PA, E \\
\hline Neem & Azadirachta indica & 451 & 18 & 200 & 669 & I & $\mathrm{LF}, \mathrm{PA}, \mathrm{T}$ \\
\hline Nispero & Manilkara chicle & 17 & 31 & & 48 & $\mathrm{~N}$ & $\mathrm{~F}, \mathrm{PA}$ \\
\hline Noni & Morinda citrifolia & 0 & 28 & & 28 & I & $\mathrm{M}, \mathrm{PA}$ \\
\hline Ojoche & Brosimum alicastrum & 10 & 0 & & 10 & $\mathrm{~N}$ & $\mathrm{PA}, \mathrm{FL}$ \\
\hline $\begin{array}{l}\text { Palma de } \\
\text { Coyol }\end{array}$ & Acrocomia mexicana & 2 & 0 & & 2 & $\mathrm{~N}$ & $\mathrm{~F}, \mathrm{~T}$ \\
\hline Palmera & Manicaria saccifera & 203 & 23 & & 226 & $\mathrm{~N}$ & $\mathrm{~T}$ \\
\hline Panama & Sterculia apetala & 19 & 0 & & 19 & $\mathrm{~N}$ & $\mathrm{PA}$ \\
\hline Papaya & Carika papaya & 5 & 153 & 57 & 215 & $\mathrm{~N}$ & $\mathrm{~F}, \mathrm{M}$ \\
\hline Pera de agua & Syzygium malaccense & 2 & 0 & & 2 & I & $\mathrm{F}$ \\
\hline Pino & Pinus ocarpa & 0 & 2 & & 2 & $\mathrm{~N}$ & PA \\
\hline Pochote & Bombascopsis quinata & 49 & 24 & & 73 & $\mathrm{~N}$ & $\begin{array}{l}\text { W, PA, } \\
\text { FW }\end{array}$ \\
\hline Quebracho & Lysiloma divaricatum & 56 & 0 & & 56 & $\mathrm{~N}$ & $\begin{array}{l}\text { W, PA, } \\
\text { FW, LF }\end{array}$ \\
\hline Roble & Tabebuia rosea & 34 & 28 & & 62 & $\mathrm{~N}$ & $\begin{array}{l}\text { W, PA, } \\
\text { FW, LF }\end{array}$ \\
\hline Sacuanjoche & Plumeria rubra & 1 & 29 & & 30 & $\mathrm{~N}$ & PA \\
\hline Sardinillo & Tecoma stans L. HBK & 44 & 0 & & 44 & $\mathrm{~N}$ & PA, FW \\
\hline Soroncontil & Cassia reticullata & 0 & 1 & & 1 & $\mathrm{~N}$ & PA \\
\hline Sungano & Licania platypus & 18 & 0 & & 18 & $\mathrm{~N}$ & F,PA, E \\
\hline Tamarindo & Tamaridus indica L. & 38 & 27 & & 65 & I & $\begin{array}{l}\text { F, LF, } \\
\text { FW, PA, } \\
\text { W }\end{array}$ \\
\hline Teca & Tectona grandis & 0 & 120 & & 120 & I & $\mathrm{W}$ \\
\hline Tiguilote & Cordia dentata Poir & 315 & 3254 & & 3569 & $\mathrm{~N}$ & $\begin{array}{l}\text { LF, PA, } \\
\text { FW, W, } \\
\text { FL }\end{array}$ \\
\hline Trinitaria & Bouganivillea glabra & 0 & 6 & & 6 & I & PA, LF \\
\hline Uva & $\begin{array}{l}\text { Arctostaphylos uva- } \\
\text { ursi }\end{array}$ & 0 & 3 & & 3 & I & $\mathrm{PA}, \mathrm{F}$ \\
\hline Zapote Mico & $\begin{array}{l}\text { Couraupita } \\
\text { nicaraguensis DC. }\end{array}$ & 1 & 0 & & 1 & $\mathrm{~N}$ & $\mathrm{~Pa}, \mathrm{~F}$ \\
\hline $\begin{array}{l}\text { Zapote, } \\
\text { Mamey }\end{array}$ & Pouteria sapota & 3 & 55 & & 58 & $\mathrm{~N}$ & $\mathrm{~F}, \mathrm{PA}$ \\
\hline Zapotillo & Prunus capouli & 2 & 0 & & 2 & $\mathrm{~N}$ & $\mathrm{~F}$ \\
\hline
\end{tabular}

(Maluenda et al. 2002, Pineda 2006, Garen et al. 2011) 